Agata A. Kluczek (Katowice)

\title{
FACES Of AEnEas. Representations on Roman Coins and Medallions
}

\begin{abstract}
$\mathrm{A}$ eneas (Aineias), the Trojan exile, his fate, personality and role in the Mediterranean world, his life story sine qua non of the Roman history, has become an interesting object of study. Here, especially, the circulating literary accounts of Aeneas' adventures provide material for such analyses of his portrait ${ }^{1}$. Also in ancient art the image of Aeneas as the progenitor of the Roman people is far from modest. In this context I focus upon the monetary representations of Aeneas in Roman coinage. This view includes republican and imperial coins as well as provincial and 'pseudo-autonomous' coins and medallions.

Aspects of Aeneas's image, based on numismatic sources, become a recurring theme of numerous studies ${ }^{2}$ in which, however, either because of the abundance of material analyzed or a too-narrow a set of numismatic references, the specific traits of Aeneas's numismatic iconography and the sense of the Aeneas motif have been lost or deformed. In the present study too I do not pretend to have exhausted the theme. I principally explore those aspects of Aeneas's image that become manifest through the way he is portrayed in the company of his family members and entourage, and placed in a definite framework referring to the prebeginnings and the history of the Roman people, as suggested by various attributes in the monetary iconography as well.

A review of monetary representations used within a period of a few centuries in the Roman world, shows how rare direct Aeneas-related motifs were ${ }^{3}$. Moreover,

\footnotetext{
${ }^{1}$ E.g. G.K. Galinsky, Aeneas, Sicily, and Rome, Princeton 1969; G. Vanotti, L'altro Enea. La testimonianza di Dionigi di Alicarnasso, Roma 1995; M. Bettini, M. Lentano, Il mito di Enea. Immagini e racconti dalla Grecia a oggi, Torino 2013.

${ }^{2}$ T. Duncan, The Aeneas Legend on Coins, CJ 44, 1948/1949, p. 15-29; W. Fuchs, Die Bildgeschichte des Flucht des Aeneas, [in:] ANRW, vol. I/4, ed. H. Temporini, Berlin-New York 1973, p. 615-632; P. AichHolzer, Darstellungen römischer Sagen, Wien 1983, p. 1-29; M. Krumme, Römische Sagen der antiken Münzprägung, Marburg 1995, p. 22-25, 94-111; A. Kendall, The depictions of Aeneas in Roman numismatic and medallic art, The Picus 1996, p. 22-37; R. CAPPELLI, Questioni di iconografia, [in:] Roma, Romolo, Remo e la fondazione della città. Roma, ed. A. CARANDini, R. CAPPelli, Milano 2000, p. 151-183; C. Mc InNIS, Foundation Iconography on Roman Coins: A Study of the Romulus and Remus and Aeneas Legends, CMNSJ 2/1, 2001, p. 5-22.

${ }^{3}$ Cf. J.-P. Martin: Les thèmes de l'épopée romaine dans la numismatique impériale, [in:] Imago Antiquitatis. Religions et iconographie du monde romain. Mélanges offerts à Robert Turcan, ed. N. BLANC, A. Buisson, Paris 1999, p. 331, 335-337.
} 
as a reverse theme, Aeneas was introduced relatively late. While in Greek coinage, the oldest known image of Aeneas can be seen on the tetradrachms of Aeneia on the Chalcidic peninsula dating back to the end of the $6^{\text {th }}$ century $\mathrm{BC}^{4}$ and recurs at the turn of the $5^{\text {th }}$ to $4^{\text {th }}$ century $B C^{5}$. While in the Roman world, Aeneas appears on the coins, as presumed, and depending on the admitted chronology of definite emissions and the identification of the iconographic representations, as late as the second half of the $3^{\text {rd }}$ century $\mathrm{BC}^{6}$ or the end of the $2^{\text {nd }}$ century $\mathrm{BC}^{7}$. Yet, there are also opinions that it was in the $1^{\text {st }}$ century $\mathrm{BC}^{8}$.

Emissions with the Aeneas motif are limited to several cases only in republican and imperial coinage. At the same time, the circulating issues were accumulated in the declining Republic, under Augustus and during the Julio-Claudian dynasty; they appeared occasionally in the Year of the Four Emperors and during the period of the Adoptive and Antonine Emperors 9 . In terms of content they are enriched by the imperial medallions from the $2^{\text {nd }}$ century ${ }^{10}$ and the medallions and the contorniates from the $4^{\text {th }}$ century ${ }^{11}$.

\footnotetext{
${ }^{4}$ E. Babelon, Traité des monnaies grecques et romaines (cetera: Bab. Traité), vol. II.1, Paris 1907, no 1556; H. Gaebler, Die antiken Münzen Nord-Griechenlands, Makedonia und Paionia, Berlin 1935 , p. $20-21$, no 1 ( $6^{\text {th }}$ C. -480 BC); R. Texier, A propos de deux représentations archaïques de la fuite d'Énée, RA 14, $6^{\text {th }}$ s., 1939, p. 16-18 (ca. 550 BC); A. AlföLd, Die trojanischen Urahnen der Römer, Basel 1957, p. 17; W. Fuchs, op. cit., p. 617-618 (ca. 500 BC); M. PriCE, N. WaGgoner, Archaic Greek Coinage. The Asyut Hoard, London 1975, p. 43-44 (490-480 BC).

${ }^{5}$ A Catalogue of the Greek Coins in the British Museum, ed. R.S. Poole, London 1873-1927 (cetera: $B M C$ ), Macedonia, Aeneia, p. 41, nos 1-5; Bab. Traité 2/1, nos 1557-1558; Bab. Traité 2/4, Paris 1926, no 925, nos 927-930 (Ascanius); H. Gaebler, op. cit., p. 21, nos 2-5, p. 22, nos 8-10. Cf. M. Mielczarex, Mennictwo starożytnej Grecji. Mennictwo okresów archaicznego i klasycznego, vol. I, Warszawa-Kraków 2006, p. 89.

${ }^{6}$ BMC Sicily, Segesta, p. 137, nos 59-61; cf. A. AlföLdi, Die trojanischen Urahnen..., p. 29; G.K. GALINSKy, op. cit., p. 173. M.H. Crawford, Roman Republican Coinage, Cambridge 1974 (cetera: RRC), nos 28/1-2, 29/1-2; cf. F. CANCIAnI, Aineias, [in:] Lexicon iconographicum mythologiae classicae, ed. L. KAHIL, vol. I.1, Zürich-München 1981, no 178.

${ }^{7}$ RRC, no 308/1a-b; cf. S. Petrillo Serafin, La pietas di Enea: due monete a confronto, BA 13, 1982, p. 37-38, n. 20; I. BIтTo, Per una proposta di interpretazione del denarius del monetiere M. Herennius con leggenda PIETAS, Messana 3, 1990, p. 147-168; EADEM, M. Herennio, il mito eneico, la dea Herentas, [in:] La tradizione iconica come fonte storica: il ruolo della numismatica negli studi di iconografia, ed. M. Caccamo Caltabiano, D. Castrizio, M. Puglisi, Reggio Calabria 2004, p. 385-388; J.D. Evans, The Art of Persuasion, Political Propaganda from Aeneas to Brutus, Ann Arbor 1992, p. 37. ${ }^{8} R R C$, no 458/1; cf. W. Fuchs, op. cit., p. 625-626.

${ }^{9}$ Cf. W. Fuchs, op. cit., p. 624-625; F. CANCiani, op. cit., nos 128-141; M. KRUmme, op. cit., p. 98-107; Kat. 21/1, 23/1, 31/1-33/1, 37/1, 48/8, 59/1-3, 93/1-95/3; A. DardenaY, Les mythes fondateurs de Rome. Images et politique dans l'Occident romain, Paris 2010, p. 77-81.

${ }^{10}$ Cf. F. Canciani, op. cit., nos 142-144, 169-172; M.R. Jenkins, Mythological narrative art in Roman numismatics, Diss. Univ. of Tasmania 1991, p. 50-66, 108-121, 153-156; M. KRUMme, op. cit., p. 107-117; Kat. 56/1-57/1, 67/1, 85/1, 92/1. J.M.C. ToynbeE, Roman Medallions, New York 1986, p. 142-144; A. DARDENAY, Les mythes..., p. 121-122.

${ }^{11}$ The Roman Imperial Coinage (cetera: RIC), 7, ed. P.M. BruUn, London 1966, p. 334, no 317; A. Alföldi, E. Alföldi, C.L. Clay, Die Kontorniat-Medaillons, Berlin 1976, p. 202, nos 90-91, p. 6,
} 
On the other hand, more often and cumulatively over a longer time perspective (from the latter part of the $1^{\text {st }}$ century until the 50 s of the $3^{\text {rd }}$ century), the Aeneas motif occurred on coins struck in the Roman East. It was featured, among others, on the reverse sides of provincial coins from Corinth, Coela in Thrace, Patras in Achaea, Apamea in Bithynia-Pontus, Otrus in Phrygia, Berytus in Phoenicia, Parium in Mysia, and from Antandrus, Dardanus and Scepsis in Troas ${ }^{12}$.

Obviously Ilium could not be missing among these cities. Here the Aeneas motif was commonly explored in the 'pseudo-autonomous' coinage under the Flavians and Antonines $^{13}$ and also in the provincial coinage under Augustus (27 BC - $14 \mathrm{AD}$ ), Hadrian (AD 117-138), Marcus Aurelius (AD 161-180), Lucius Verus (AD 161-169) and Elagabalus (AD 218-222) ${ }^{14}$. On the other hand, in the western part of the Mediterranean, the Aeneas motif can be found on the coins of Segesta in Sicily ${ }^{15}$.

no 20, p. 114-115, no 349, p. 117, no 355; F. Canciani, op. cit., no 145; M.R. Jenkins, Mythological narrative art..., p. 270-271.

${ }^{12}$ E.g. Corinth - Roman Provincial Coinage (cetera: RPC), 4, no 5152 temp. (Marcus Aurelius), 5225 temp., 9502 temp. (Commodus); Coela - RPC 9, no 164 temp. (Trebonianus Gallus); http://www. ancientcoinage.org/the-trojan-war.html [13 IV 2016] (Gallienus); Patras - BMC Peloponnesus, Patrae, p. 28, no 44; RPC 4, no 4623 temp., 9879 temp. (Commodus); Apamea - RPC, 3, no 1032 (Hadrian); BMC Pontus, Apamea, p. 114, no 37 (Severus Alexander); Otrus - H. von Aulock, Münzen und Städte Phrygiens, Tübingen 1980 (cetera: vA Phrygiens), nos 787-789 (Caracalla), no 816, 835; BMC Phrygia, Otrus, p. 345, no 14 (Geta); Berytus - BMC Phoenicia, Berytus, p. 84, nos 213-215 (Elagabalus); Parium - http://www.ancientcoinage.org/the-trojan-war.html [13 IV 2016] (Gallienus); Antandrus - C. FonTANA, Note su alcune monete inedite o poco conosciute della serie urbica greca coniate durante l'Impero Romano, RINSA 18, 1967, p. 54, no 18 (Caracalla); A. Giampaglia, Enea, il fondatore: Roma e la Troade a confronto, [in:] Polis, urbs, civitas, moneta e identità, ed. L. TravaInI, G. ArRIGONI, Roma 2013, p. 160; https://www.cngcoins.com/Coin.aspx?CoinID=114901 [13 IV 2016] (Severus Alexander); Dardanus - RPC 3, no 1561 (Trajan); BMC Troas, Dardanus, p. 51, no 29 (Geta); Sylloge Nummorum Graecorum Deutschland: Sammlung von Aulock, rev. G. KLEINER et al., Berlin 1957-1968 (cetera: SNG vA), no 1505; RPC 4, no 67 (Crispina); Scepsis - http://www.ancientcoinage.org/the-trojan-war.html [13 IV 2016] (Faustina II); K. KrafT, Das System der kaiserzeitlichen Münzprägung in Kleinasien. Materialien und Entwürfe, Berlin 1972, p. 161, no 27 (Julia Domna); BMC Troas, Scepsis, p. 85, no 38 (Julia Mamaea). Cf. K.W. HARL, Civic Coins and Civic Politics in the Roman East A.D.180-235, Berkeley-Los Angeles-London 1987, p. 74; R. Lindner, Mythos und Identität: Studien zur Selbstdarstellung kleinasiatischer Städte, Stuttgart 1994, p. 45-64; Ch. Howgego, Coinage and Identity in the Roman Provinces, [in:] Coinage and Identity in the Roman Provinces, ed. Ch. Howgego, V. Heuchert, A. Burnett, Oxford-New York 2005, p. 5-6. ${ }^{13}$ H. von Fritze, Die Münzen von Ilion, [in:] Troja und Ilion: Ergebnisse der Ausgrabungen in den vorhistorischen und historischen Schichten von Ilion 1870-1894, ed. W. Dörpfeld, 2, Athen 1902 (cetera: vF Ilion), nos 28-31; BMC Troas, Ilium, p. 59, no 20; A.R. Bellinger, Troy. The Coins, Princeton 1961, nos T 129, 140, 141, 208, 210; SNG vA, nos 1524-1526; RPC 3, no 1577; RPC 4, no 2487 temp. ${ }^{14} \mathrm{vF}$ Ilion, no 41; BMC Troas, Ilium, p. 60, no 28; A.R. Bellinger, op. cit., no T 115; RPC 1, no 2306 (Augustus); vF Ilion, no 55; SNG vA, no 1533; A.R. Bellinger, op. cit., no T 134; RPC 3, no 1570 (Hadrian); vF Ilion, no 62; A.R. Bellinger, op. cit., no T 148; RPC 4, no 85 (Marcus Aurelius); A.R. Bellinger, op. cit., no T 154; RPC 4, no 91 (Lucius Verus); https://www.pecunem.com/ auction-24/lot-296 [15 XII 2015] (Elagabalus).

${ }^{15}$ BMC Sicily, Segesta, p. 137, nos 59-61; R. CALCiaTI, Corpus nummorum siculorum: la monetazione di bronzo, vol. I, Milano 1983, Segesta, p. 304, nos 54, 56, 57; M. KRUmme, op. cit., p. 98, Kat. 155/1. 
It is striking how popular the Aeneas motif was in the numerous minting centres that produced pseudo-autonomous and provincial coins in the times of the Empire, and how modestly it was represented in the parallel imperial coinage.

This observation stands in contrast to Aeneas' role as the progenitor of the Romans. He appears more as a hero of the Roman East than of the whole Roman world. Especially on the coins minted in the city of Ilium he was a symbol of the city's identity by the reference to its mythological beginnings. Moreover, the inscription:

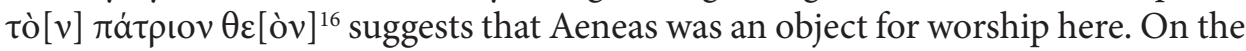
other hand, in Italia and especially in Lavinium, Aeneas became a local hero for whom a heroon was erected with the inscription: $\pi \alpha \tau \rho \grave{\varsigma} \varphi \theta \varepsilon o \tilde{v} \chi \theta o v$ íov $^{17}$. Another way of distinguishing Aeneas was by calling him indigens pater, who in deorum numero relatus (est) which can be seen in the inscription on the Domus Eumachiae next to the Pompeii forum ${ }^{18}$. Furthermore, within the multi-branched Greek and Roman tradition relating to Aeneas, it was sometimes to him that the foundation of Rome was ascribed ${ }^{19}$.

A rather modest representation of the Aeneas motif in Roman coinage and its narrow chronological frame are due to the specific character of the numismatic sources and to the fact that it was relatively late that the exile from Troy became associated with the future of the Romans. After all, the story of Aeneas was continually transformed, both in ancient literature and in works of art, their episodes being nuanced in various ways. There exists a wide range of possibilities between Aeneas mentioned in the Iliad and Aeneas as the embodiment of a supreme religious and political idea in the Aeneid ${ }^{20}$. Still the precondition for introducing him into monetary iconography was that the contemporary coin issuers noticed a quasi-genealogical relationship to him or his independent ideological attractiveness. For this reason two clear-cut caesuras are revealed in Roman coinage: one of them falls at the time of the declining Republic and Augustus's reign, when both of the aforementioned conditions were fulfilled, and the other becomes manifest under Hadrian (117-138 AD) and Antoninus Pius (138-161 AD), when the second condition is fulfilled.

Cf. G.K. Galinsky, op. cit., p. 173; M.C. Caltabiano, Gli eroi omerici nella tipologia monetale antica, RINSA 90, 1988, p. 28.

${ }^{16}$ CIG 3606, [in:] Corpus Inscriptionum Graecarum, ed. A. Boeckhius, Berolini 1843; Iv Ilion 143, [in:] P. FrIsCH, Die Inschriften von Ilion, Bonn 1975.

${ }^{17}$ D.H., I, 64, 5, [in:] Dionysi Halicarnasiensis Antiquitatum Romanarum quae supersunt, ed. C. JAсовY, Lipsiae 1885-1905 (cetera: D.H.).

${ }^{18}$ CIL X, 808 = 8348, [in:] Corpus Inscriptionum Latinarum, ed. Th. Mommsen, Berolini 1883.

${ }^{19}$ Hellanicos, in D.H., I, 72, 2; Sall., Cat. 6, [in:] C. Sallustii Crispi Catilina, post A.W. Ahlberg ed. A. Kurfess, Lipsiae 1972 (cetera: SAll., Cat.)

${ }^{20}$ Cf. (e.g.) N.M. Horsfall, The Aeneas-Legend from Homer to Virgil, BICS 34, 1987, Suppl. Nr 52: Roman Myth and Mythography, p. 12-24; IDEM, Aeneas the colonist, Verg 35, 1989, p. 8-27. 
A review of the occurrence of the Aeneas motif reveals that there were few iconographic models used in Roman coinage. The catalogue that Fulvio Canciani made on the basis of the Aeneas representations in the works of ancient art familiar to him, enumerates over 20 different models ${ }^{21}$. Only three of them can be found on the reverses of the Roman coins. They refer to the themes, which the Italian researcher defines as the flight from Troy, the arrival in Italy and the pact with Latinus, yet in their content they also comprise the first offering made on Italian land and the foundation of the city.

Such a course of events, arranged according to the legendary chronology, and complemented by successive episodes, reveals itself in the inscription on the base of a statue that once stood in Pompeii:

Aenea[s Ven]eris et Anchisa[e filius Troia]nos / qui capta Tr[oia et incensa s] uper / [fue]rant in It [aliam adduxit] /.../ [oppidum Lavinium] con[didit .../... regnavit an] nos tris in / [bel] lo Lauren[tin] o non con / [pa]ruit appel[latus]q est indigens / [pa]ter et in deo[rum n] umero relatus ${ }^{22}$.

The episodes of Aeneas' life, rendered symbolically on the coins, are set within the framework of the same canonical associations.

A model that was most commonly used on the reverses of provincial coins was the three-person Aeneas group, consisting of Aeneas carrying his father Anchises on his arm and holding his son Ascanius by the hand. On the imperial coins, however, the Aeneas Group was depicted rather rarely and usually played a secondary role.

As an example, on the sestertii of Caligula it adorns, together with other sculptures, the fastigium of the temple of the divus Augustus on the Palatine hill ${ }^{23}$; the same detail can also be found on some variants of Antoninus Pius coins, depicting templum or aedes divi Augusti restituta ${ }^{24}$. On the other hand, on the sestertii PIETAS AVGVSTI S C of Galba, the Aeneas Group is featured in the relief frieze of an altar at which Pietas makes her offering ${ }^{25}$. A complement to this group

${ }^{21}$ F. CANCIAni, op. cit., p. 381-394. See, e.g., subjects indicated by A. Dardenay, Images des Fondateurs. D'Enée à Romulus, Bordeaux 2012, p. 13-75: "la Fuite d’Énée" and "les images secondaires illustrant la légende troyenne".

${ }^{22}$ See note 18 above. Aeneas' elogium - CIL VI, $40931=$ AE 1934, $149=$ AE 1938, 4 = AE 1949, 165 $=\mathrm{AE} 1999,177$.

${ }^{23}$ The Roman Imperial Coinage, ed. H. Mattingly et al., London 1923 sqq (cetera: RIC), 12, Calig., nos 36, 44, 51; A Catalogue of the Roman Coins in the British Museum. Coins of the Roman Empire in the British Museum, ed. H. Mattingly, London 1965-1976 (cetera: BMCRE), 1, Calig., no 41; M. KRumme, op. cit., p. 104, Kat. 31/1; cf. G. Fuchs, Architekturdarstellungen auf römischen Münzen der Republik und der frühen Kaiserzeit, Berlin 1969, p. 45.

${ }^{24}$ RIC 3, Ant.P., nos 124, 143, 272a-b, 284, 289-290, 755, 787, 795-796, 973, 978, 988, 994, 998,

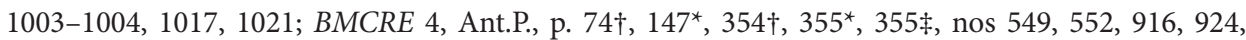
938-939, 1652, 1718, 1729-1730, 2051, 2063-2066, 2098; M. KRUмme, op. cit., p. 104, Kat. 93/1a-95/3.

${ }^{25}$ BMCRE 1, Galba, p. 358 $\$$; RIC 12 ${ }^{2}$, Galba, no 483; M. KrUmME, op. cit., p. 104, Kat. 37/1. 
is a Hadrian medallion of a VENERI GENETRICI type. Here the motif of the Aeneas group adorns the shield on which the goddess Venus is sitting ${ }^{26}$. Placing the Aeneas Group within the ornamental elements of a temple, an altar or a shield indicates that the motif was characteristic and easily recognizable. However, the Aeneas group rarely appears as the main element of reverse iconography in imperial coinage ${ }^{27}$; the model was par excellence typical for provincial coinage where such pictures were widespread, lasting and only slightly diversified. It implies the iconographic and compositional dependence of these monetary representations upon a common source or a widely known work ${ }^{28}$.

It seems that the inspiration came from the statuary representation of the Aeneas group, raised in the Forum of Augustus in Rome in the 20s of the $1^{\text {st }}$ century $\mathrm{BC}^{29}$. At the same time, in the strophes of the Aeneid, Virgil pictures Aeneas fleeing from the city of Troy:

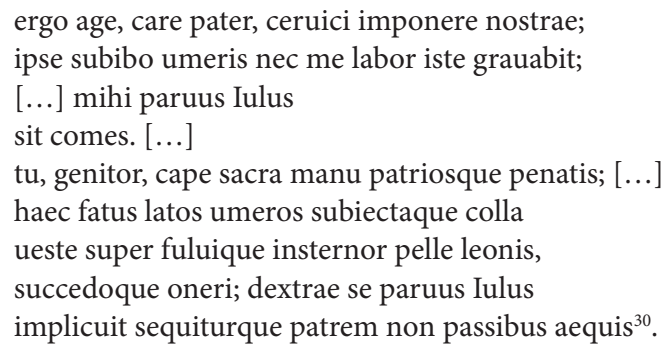

On the basis of these words, it is easy to compose an image that recalls the one known from the monetary representations, where Aeneas, carrying his father on his back and leading his son by the hand, is shown as profugus ${ }^{31}$. Still, the sculpture from the Forum of Augustus did not survive into our times. We can find only a very general description of it in Ovid:

\footnotetext{
${ }^{26}$ F. GNeCCHI, I medaglioni romani, descritti ed illustrati, Milano 1912, 3, Adr., no 92. References to Venus and her son Aeneas may be associated with an allusion to the mythical ancestress of the Julian family, and to the dynastic idea, cf. P. ZANker, August i potegga obrazów, przeł. L. Olszewski, Poznań 1999, esp. p. 101, 198 sqq; O. HeKster, Emperors and Ancestors: Roman Rulers and the Constraints of Tradition, Oxford 2015, esp. p. 239-241.

${ }^{27}$ F. GNecchi, I medaglioni..., 3, Ant.P., no 158; RIC 3, Ant.P., nos 91, 615, 627; BMCRE 4, Ant.P., nos 237, 1264, 1292; M. Krumme, op. cit., p. 104, Kat. 59/1-3.

${ }^{28}$ Cf. vF Ilion, p. 519.

${ }^{29}$ W. Fuchs, op. cit., p. 627-629: ca. 27-22 BC. Cf. F. CANCIANI, op. cit., no 146.

${ }^{30}$ Vergilius, Aen. II, 707-708, 710-711, 717, 721-724, [in:] Virgile, Énéide, trans. et ed. J. Perret, Paris 1987-1993 (cetera: Verg., Aen.).

${ }^{31}$ Verg., Aen. I, 2. Cf. Verg., Aen. VII, 300; VIII, 118; X, 158; Liv., I, 1, 5 and 8, [in:] Tite-Live, Histoire romaine, trans. et ed. R. Bloch, J. BAYET, G. BAILlEt et al., Paris 1968 sqq (cetera: Liv.); SAll., Cat. 6. Cf. V. Rimell, The Closure of Space in Roman Poetics. Empire's Inward Turn, Cambridge 2015, p. 34,70 .
} 
Hinc uidet Aenean oneratum pondère caro

et tot Iuleae nobilitatis auos;

hinc uidet Iliaden umeris ducis arma ferentem ${ }^{32}$.

The painting on the facade of the fullonica in Via dell'Abbondanza in Pompeii is presumed to depict the Roman sculpture of Aeneas with his father and son (cf. fig. 1) ${ }^{33}$. The painting reproduces the composition of the statue that once stood on the facade of Domus Eumachiae in Pompeii, which itself was a copy of a Roman prototype $^{34}$. The presence of the Aeneas group in the relief of Sebasteion in Aphrodisias $^{35}$ and in numerous monuments of major and minor art such as altar reliefs, gems, clay lamps, and others testifies to its popularity (cf. fig. 2).

In the literature and visual arts of the period, from which images of the Aeneas group became popular in the coinage, there was a certain convention in depicting the Trojan hero. Different monetary designs in which it was reproduced prove that this portrait of Aeneas was so universal that it was adopted in diverse geographic and chronological environments. The inspiration was presumably drawn, directly or indirectly, from the Roman statuary prototype. This reasoning is justified by the chronological order in which the monetary representations of the Aeneas group developed. Still, the entire group of these coins repeated, in a transformed iconographic version, what was a part of Aeneas' myth as it functioned in the times of Augustus. We can see here the conservatism of coin representations, which exhibit far fewer individual variants than, for example, the ornaments on contemporaneous lamps that also depict the Aeneas group ${ }^{36}$, and the permanence of the model. On the other hand, the elements suggesting the relation between the Trojan hero and the foundation of Rome, were a reference to Augustan times, when the conviction about the exceptional role played by Aeneas was excessively developed and established.

These features of the model - permanence, schematism - indicate a symbolic value of the Aeneas group in numismatic imagery. The fact of drawing from this model, well-established in provincial coinage, proves that it was referred to in order to show the connection with the Roman state either of the Julian colonies, or the towns benefiting from pax romana, or simply the places, which via the mythical stories, were somehow related to Aeneas' journey. On the other hand, in the original iconography found on the reverses of the medallions, the figures of Aeneas and

\footnotetext{
${ }^{32}$ Ovidius, Fasti, V, 563-665, [in:] Ovids's Fasti, trans. J.G. Frazer, London-Cambridge Mass. 1959 (cetera: Ov., Fast.).

${ }^{33}$ F. CANCIANI, op. cit., no 98.

${ }^{34}$ Ibidem, no 147.

${ }^{35}$ R.R.R. Smith, Myth and Allegory in the Sebasteion, [in:] Aphrodisias Papers: Recent work on architecture and sculpture, ed. Ch. Roueché, K.T. ERIM, JRA Suppl. 1, 1990, p. 97-100.

${ }^{36}$ Cf. W. Fuchs, op. cit., p. 629; A. DARdenaY, Le rôle des ateliers de lampes dans la diffusion iconographique de la fuite d'Énée, MCV 35.2, 2005, p. 161-189.
} 
his relatives are woven into the scenes which explain the episodes from the Trojan's life with references to associations other than the Aeneas group.

The early representations in Roman coinage depict Aeneas with Anchises only $^{37}$. The son of the hero, Ascanius, was only introduced later, on emissions featuring the Aeneas group.

Ascanius (Askanios), which is peculiar especially to the iconographic representations of Aeneas in the Greek world, did not appear frequently nor did it play a primary role. We do not find him in the earliest preserved representation of Aeneas' flight from Troy in the vase painting (ca $540 \mathrm{BC})^{38}$. Sometimes, however, a child or even more children appear in the pictorial decorations of the Greek vases in the $6^{\text {th }}$ and $5^{\text {th }}$ century $\mathrm{BC}^{39}$, which would correspond to the version of Aeneas' numerous offsprings. Still, in the $2^{\text {nd }}$ century BC Cassius Hemina mentions that two of Aeneas' sons were lead out of Troy ${ }^{40}$.

In Italia, Ascanius was called Julus. This change of name was to signify maturity: a youth took part in the war, hair began growing on his face ${ }^{41}$. Creusa was supposed to call her son Ilius, first he was called Iolus, then Iulus. These changes of name establish a closer relationship between Ascanius, or the Trojan tradition on one side and the gens Iulia on the other ${ }^{42}$.

This genealogical connection with the Trojans - via Ascanius - is not reflected in the coin imagery of the declining Republic and the beginning of the Empire. It is striking that Ascanius is absent from the coins related to the person of C. Julius Caesar and Octavian, in these cases the representation is confined to Aeneas and Anchises. It would be a trace of the Greek tradition established, for example, in the

\footnotetext{
${ }^{37}$ Cf. the denarii of M. Herennius - H.A. Grueber, Coins of the Roman Republic in the British Museum, London 1910 (cetera: BMCRR), Rome, nos 1231-1258 (ca. 91 BC); E.A. Sydenham, The Coinage of the Roman Republic, London 1952 (cetera: CRR), nos 567-568 (101 BC); RRC, nos 308/1a-b (108 or 107 BC); Caesarian denarii - BMCRR East, p. 469, nos 31-35 (48 BC); CRR, no 1013 (48 BC); RRC, no 458/1 (47-46 BC); M. KRUMme, op. cit., p. 94, 98-100, Kat. 21/1; denarii of L. Regulus - BMCRR Rome, nos 4257-4258 (ca. 39 BC); CRR, nos 1104-1104a (42 BC); RRC, nos 494/3a-b (42 BC); M. KRUmme, op. cit., p. 101-102, Kat. 23/1. See also BMC Sicily, Segesta, p. 137, nos 65, 66; R. Calciati, op. cit., Segesta, p. 305, no 61; RPC 1, no 652; M. Krumme, op. cit., p. 98, Kat. 164/1; and vF Ilion, no 41; BMC Troas, Ilium, p. 60, no 28; A.R. Bellinger, op. cit., no T 115; RPC 1, no 2306.

${ }^{38}$ F. Canciani, op. cit., no 59.

${ }^{39}$ Child - F. CANCIANI, op. cit., no 60 (ca. 520 BC); see http://www.perseus.tufts.edu/hopper/imag e?img=Perseus:image:1992.06.1379 [17 XII 2015]; also F. CANCIANI, op. cit., nos 63-65, 67-69, 87; children - ibidem, nos 66, 79.

${ }^{40}$ Hem. in Servius, Aen. II, 717: Idem historiarum libro I ait, Ilio capto (Aenean cum dis pena)tibus umeris impositis empisse duosque filios Ascanium et Eurybaten bracchio eius innixos ante ora hostium praetergressos [...], [in:] Servii Grammatici qui feruntur in Vergilii carmina commentarii, rec. G. Thilo, Lipsiae 1881, 1884 (cetera: SERv., Aen.).

${ }^{41}$ Serv., Aen. I, 267 and 286.

${ }^{42}$ Liv., I, 3, 2; App., Civ. II, 10, 68, [in:] Appian's Roman History, trans. H. White, London-Cambridge Mass. 1964 (cetera: App.); Serv., Aen. I, 267. Cf. further A. Erskine, Troy between Greece and Rome. Local tradition and imperial power, Oxford 2001, p. 17-23; O. Некster, op. cit., p. 240-250.
} 
statue from the island of Cos $\left(2^{\text {nd }}\right.$ century BC) that repeats the composition wellknown earlier in the East, and also in the statuette from Kharayeb in Lebanon $\left(4^{\text {th }}-1^{\text {st }} \mathrm{BC}\right)^{43}$.

It is only on the imperial coins from the times of Caligula (AD 37-41), as previously mentioned, that the whole three-person Aeneas Group was portrayed. Yet, it was just a detail here, not the main theme of the reverse conception. Besides, this second version of the image was introduced late and remained predominantly an iconographic motif of the provincial issues. Within the regular imperial coinage it appears only during the reign of Antoninus Pius.

In these official numismatic declarations, for the issuers and authors of the monetary designs, Ascanius was not an obvious link between the history of the Trojans and that of the Romans. Furthermore, within the most numerous group of the representations in which he appears, Ascanius is only a single element of the Aeneas Group, a complement to the central figure of Aeneas.

It is Aeneas himself who remains the thread binding the Romans with the Trojans and the condition sine que non of the Roman future. The appearance of both Anchises and Ascanius is optional, which proves that - in order to recall the relationship with the Trojan hero and his significance for the Roman history - the message was built up around Aeneas. The figures of Anchises or Ascanius are also interchangeable: the introduction of one or the other entailed different associations.

The presence of Anchises serves to emphasize the caritas and pietas of the Trojan hero. Even though, the image of Anchises, walking behind Aeneas functioned in Greek art ${ }^{44}$, in monetary iconography Anchises - always lame, old and therefore unable to leave Troy on his own - is saved solely by his son who, burdened with his father, becomes pius ${ }^{45}$.

On the imperial coins of Antoninus Pius ${ }^{46}$, on 'pseudo-autonomous' coins of Ilium, issued in the times of the Flavians ${ }^{47}$, on the provincial coins from Apamea, issued in the times of Hadrian ${ }^{48}$, and on those from Otrus with the portrait of Geta ${ }^{49}$ etc., the object that deserves attention is the small cista or pyxis, held by Anchises. However, it is difficult to establish if the detail, which is rather small,

\footnotetext{
${ }^{43}$ W. Fuchs, op. cit., p. 622; A. DARDEnaY, Les mythes..., p. 47.

${ }^{44}$ Lekythos, Gela, $480 / 470$ BC; metope $28 \mathrm{~N}$ of the Parthenon, 447-438 BC, cf. W. Fuchs, op. cit., p. 619-620; F. CANCIANI, op. cit., nos 155, 156.

${ }^{45}$ E.g. Ov., Fast. IV, 37-38: hinc satus Aeneas, pietas sceptata, per ignes / sacra patrem umeris, altera sacra, tulit. Cf. (e.g.) D.H., I, 48, 2; Lyc., Alex. 1270, [in:] Lykophron: Alexandra, ed., trans. et comm. S. Hornblower, Oxford 2015 (cetera: Lyc., Alex.); App., Civ. IV, 41; OGR IX, 1, [in:] Pseudo-Aurélius Victor, Les Origines du Peuple Romain, trans. et ed. J.-C. Richard, Paris 1983.

${ }^{46}$ RIC 3, Ant.P., nos 91, 615, 627; BMCRE 4, Ant.P., nos 237, 1264, 1292; M. KRUMme, op. cit., p. 104, Kat. 59/1-2a,b, 59/3.

${ }^{47} \mathrm{vF}$ Ilion, no 28 ; $B M C$ Troas, Ilium, p. 59, no 20 ( $2^{\text {nd }}$ c.); A.R. Bellinger, op. cit., no T 129; SNG vA, no 1524 .

${ }^{48}$ RPC 3, no 1032.

${ }^{49}$ BMC Phrygia, Otrus, p. 345, no 14; vA Phrygiens, nos 816, 835.
} 
can also be found on other coins. Probably, it was introduced into the provincial coins quite accidentally and depended on how faithful to the prototype, that is to the statue from the Roman Forum or to another source of inspiration, the image was. It is significant that a cista was surely a Roman iconographic invention as sacra were not present in the Greek tradition ${ }^{50}$ while in the Roman world they appear in numerous iconographic works ${ }^{51}$. In numismatic representations this detail accentuated the spiritual aspect of Aeneas' portrait: here he is not only his father's saviour (pietas erga parentem) but also the one who (pius duplex) brings the sacra patriosque penatis out of Troy $^{52}$ thus adopting the attitude of pietas erga patriam. Unknown remains a reverse variant with Aeneas carrying the sacra, yet within the literary tradition the merit for saving these sanctities was ascribed to him by metaphorically putting the sacra, the Penates, or the household gods, and the sacred fire of Vesta in his hands ${ }^{53}$.

Nonetheless, the leading role of Aeneas in rescuing his father, who is bringing the household gods, was rendered in the iconography through the popular model in which Anchises - carried by Aeneas - holds a cista. In this model Aeneas, carrying a double burden, becomes, metaphorically, the carrier of the household gods: a penatiger ${ }^{54}$. It expands his role as the detail binds the exile from the Teucrian land with the future of his descendants in Italy for whom the possession of these sacra is a guarantee of prosperous existence.

Due to the relationship of Aeneas with the Penates, the group of coins referring to him can be extended to include the republican denarii of C. Sulpicius (106 BC). On their obverse, two jugate heads represent the Penates, as the letters DPP ( $s c$. Dei Penates Publici) say, while the reverse depicts two men standing over a sow (fig. 3) ${ }^{55}$. It is therefore probable that one of them is Aeneas and the other is the king Latinus. They are making a pact with each other, as described much later by Virgil ${ }^{56}$. It would be one of the original images of Aeneas in Roman coinage.

On the other hand, the connection of Aeneas with the contents of the L. Papius Celsus' denarii (ca $46 \mathrm{BC}$ ), with an image of Juno on the obverse and a she-wolf

\footnotetext{
${ }^{50}$ Exceptionally - the Etruscan scarab, $5^{\text {th }}$ c. BC, Paris, Bibl. nat., Coll. de Luynes 276, R. Texier, op. cit., p. 12-21; A. AlföLdI, Die trojanischen Urahnen..., p. 15-16; F. CANCIANI, op. cit., no 95; and the Etruscan RF amphora, Vulci, 470-460 BC, Monaco, Antikesamml. 3186 - F. CANCiAnI, op. cit., no 94; G.K. Galinsky, op. cit., p. 60; contra N. Horsfall, The Iconography of Aeneas' Flight: a Pratical Detail, AK 22/2, 1979, p. 104-105.

${ }^{51}$ E.g. F. Canciani, op. cit., nos 98, 102-126, 149-151, 153-154.

${ }^{52}$ Cf. Verg., Aen. II, 717.

${ }^{53}$ E.g. Ov., Fast. IV, 37-38; Verg., Aen. I, 68-69; II, 296-297. Cf. (e.g.) Hem. in Serv., Aen. II, 717; Verg., Aen. I, 6, 378-379; II, 293-295, 717, 747-748; III, 12, 148-149; IV, 598; V, 632; VII, 120-122; VIII 10-13 and 39; XII, 191-194.

${ }^{54}$ Ov., Met. XV, 450, [in:] P. Ovidius Naso, Metamorphoses, ed. R. Ehwald, Lipsiae 1931.

${ }_{55}^{55}$ BMCRR Rome, nos 1314-1326; CRR, no 572 (103-102 BC); RRC, no 312/1 (106 BC).

${ }^{56}$ Verg., Aen. XII, 191-194.
} 
(rather than wolf) and an eagle over the flames on the reverse ${ }^{57}$, results from the fact that the story related to the foundation of Lanuvium was erroneously associated with Lavinium. Dionysius of Halicarnassus mentions prophetic signs that preceded the foundation of Lavinium by Aeneas: a wolf and an eagle were feeding the fire while a fox was trying in vain to douse it. The scene found expression in a sculpture standing in Lavinium showing a wolf, an eagle and a fox ${ }^{58}$.

Aeneas was also associated with the Palladion (Palladium), a statuette of Pallas Athena, representing the goddess, xoanon type, described by Apollodorus ${ }^{59}$. In various versions of the myth, it was supposed to be a gift for Dardanus that was kept in a temple in Troy to ensure its inviolability. Still, subsequently, Diomedes and Odysseus (Ulysses) carried the statuette away and brought it to the Greek camp ${ }^{60}$. It remains unclear how the statuette again fell into the hands of the Trojans fleeing from the falling city ${ }^{61}$. Diomedes would hand the Palladium over to Nautes or Aeneas. In Latium, Aeneas would receive it from Diomedes ${ }^{62}$. Possibly, however - as others claim ${ }^{63}$ - a copy was left to them while the original Palladium was brought to Italia by Aeneas.

The Palladium motif is featured on the coins struck in Ilium both during the Hellenistic epoch ${ }^{64}$ and in Augustan times ${ }^{65}$. It was frequently exploited on the provincial coins of Ilium, starting from the age of the Antonines. Yet, because of the dependence of the monetary motif on the said Roman sculpture, from which this detail was lacking, it does not appear as an element of the Aeneas Group, so frequently featured on these coins. However, the Palladium was pictured as an autonomous element of the reverse iconography in the $2^{\text {nd }}$ and $3^{\text {rd }}$ century ${ }^{66}$. On the

\footnotetext{
${ }^{57} B M C R R$ Rome, nos 4018-4024 and CRR, nos 964-965. Cf. RRC, nos 472/1-2: wolf.

${ }^{58}$ D.H., I, 59, 4-5. Cf. P.M. Martin, Sur un prodige délivré à Énée (D.H., I, 59, 4-5): essai d’interprétation, REL 64, 1986, p. 41-42, 57-58.

${ }^{59}$ Apoll., Bibl., III, 12, 3, [in:] Apollodorus, Epitome of the Library, trans. J.G. Frazer, London 1921.

${ }^{60}$ E.g. D.H., I, 68-69; Verg., Aen. II, 164.

${ }^{61}$ Ov., Fast. VI, 433-435: seu gener Adrasti, seu furtis aptus Ulixes,/ seu fuit Aeneas, eripuisse ferunt; I auctor in incerto, res est Romana.

${ }^{62} \mathrm{Hem}$. in Sol., II, 14: Nec omissum sit Aenean [...] ut Hemina tradii [...] in agro Laurenti posuisse castra: ubi [...] a Diomede Palladium suscepit, [in:] C. Iulii Solini Collectanea rerum memorabilium, rec. Th. Mommsen, Berolini 1895 (cetera: Sol.).

${ }^{63}$ Arctinos, in D.H., I, 69, 3, cf. ibidem, II, 66, 5.

${ }^{64}$ Inventaire sommaire de la Collection Waddington [...] ed. E. BAbelon, Paris 1898 (cetera: Bab. Wadd.), no 1151; Bab. Traité 2/2, Paris 1910, no 2398; vF Ilion, p. 511-512 and nos 3-13, 16-25; BMC Troas, Ilium, p. 57, nos 1-9; p. 59, nos 14-15. Cf. L. LACroix, Les reproductions de statues sur les monnaies grecques, Liège 1949, p. 101-131.

${ }^{65}$ Bab. Wadd., no 1155; vF Ilion, nos 26-27, 40; BMC Troas, Ilium, p. 59, nos 16-19.

${ }^{66} \mathrm{vF}$ Ilion, no 64; $B M C$ Troas, Ilium, p. 65, no 57 (Marcus Aurelius and Lucius Verus); BMC Troas, Ilium, p. 65, no 58 (Lucius Verus); no 55 (Faustina II); L. LACroIx, op. cit., p. 109 (Commodus); vF Ilion, nos 92-93; BMC Troas, Ilium, p. 68, no 78 (Julia Domna); Bab. Wadd., no 1178 (Geta); BMC Troas, Ilium, p. 71, no 99 (Gordian III); Bab. Wadd., no 1186 (Trajan Decius).
} 
emissions dating from the reign of the Antonines the statuette is set in a temple ${ }^{67}$ while on those struck under the Antonines, the Severi and Gordian III, it is placed on a column ${ }^{68}$. In the emissions under the early Severi the Palladium was depicted alongside Ilus and Hector ${ }^{69}$ while on the coins issued under Marcus Aurelius it is set in the scene with Ganymedes and an eagle ${ }^{70}$. On the coins with the portrait of Crispina, the Palladium is held by Tyche, standing beside Athena ${ }^{71}$ and in the bronze coinage at the time of Elagabalus, Aeneas, standing before Tyche, is handing over the statuette into the hands of Roma ${ }^{72}$.

The popularity of the Palladium motif on the coins from Ilium could partly be due to the fact that its inhabitants, considering themselves the successors of the Trojans, believed that the statuette had never been carried away from the city of Troy ${ }^{73}$. Likewise, other cities such as Luceria in Apulia, Siris in Lucania, Lavinium, and finally Rome also boasted possessing it $^{74}$. After all, at the very beginning of its "history" Athena's gift for Dardanus was of two statuettes deposited in Troy ${ }^{75}$.

The tradition concerning the fate of the Palladium was so diverse that it was depicted on the coins issued in the city of Dardanus in Troas, whose eponym was Dardanus (Dardanos) ${ }^{76}$. In addition, it was introduced into the Troezenian coins ${ }^{77}$ and into those minted in Synnada in Phrygia ${ }^{78}$, with some variants in which the Palladium was held by Lacedaemon ${ }^{79}$. Iconographically, however, it was more often associated with the figure of Diomedes, who apparently, was one of those who carried it away from Troy. This thread was taken up by the coins of Tyre in Phoenicia ${ }^{80}$

\footnotetext{
${ }^{67} \mathrm{vF}$ Ilion, no 58 (Marcus Aurelius).

${ }^{68}$ vF Ilion, nos 67-69; BMC Troas, Ilium, p. 64-65, nos 53-54 (Faustina II); BMC Troas, Ilium, p. 66, no 60 (Commodus); Bab. Wadd., no 1167; vF Ilion, no 85; BMC Troas, Ilium, p. 67, nos 67-68; A.R. Bellinger, op. cit., no 198; RPC 4, no 131 temp. (Crispina); Bab. Wadd., no 1168 (Septimius Severus); Bab. Wadd., no 1170; BMC Troas, Ilium, p. 68, nos 76-77 (Julia Domna); BMC Troas, Ilium, p. 69, no 86 (Caracalla); Bab. Wadd., nos 1184-1185; vF Ilion, nos 110-111 (Gordian III).

${ }^{69}$ Bab. Wadd., nos 1175-1176; vF Ilion, p. 520, 524 and nos 91, 98; BMC Troas, Ilium, p. 69-70, nos 87-89.

${ }^{70}$ Bab. Wadd., no 1160; vF Ilion, p. 525-526 and no 61; BMC Troas, Ilium, p. 64, no 51.

${ }^{71}$ vF Ilion, no 86; BMC Troas, Ilium, p. 67, no 70; A.R. BeLLINGER, op. cit., no 200; RPC 4, no 132 temp.

${ }^{72}$ https://www.pecunem.com/auction-24/lot-296 [17 XII 2015].

${ }^{73}$ E.g. App., XII, 53, 213

${ }^{74}$ Cf. Plut., Cam. 20, 5, [in:] Plutarch's Lives, trans. B. Perrin, London-Cambridge, MA 1914.

${ }^{75}$ D.H., I, 68, 3; Varro, in Serv., Aen. II, 166.

${ }^{76}$ Bab. Wadd., no 1137 (Julia Domna); Bab. Wadd., no 1138 (Severus Alexander).

${ }^{77} B M C$ Peloponnesus, Troezen, p. 167, no 19; RPC 4, no 4640 temp. (Commodus).

${ }^{78}$ Bab. Wadd., no 6540; RPC 4, no 2987 temp. (Antoninus Pius); BMC Phrygia, Synnada, p. 400, no 45; RPC 4, no 2210 temp. (Marcus Aurelius caesar).

${ }^{79}$ RPC 4, no 2205 temp. (Antoninus Pius).

${ }^{80}$ E. BABelon, Les Perses Achémenides, les satrapes et les dynasties tributaires de leur empire, Cypre \& Phénicie, Paris 1893, nos 2300, 2301; RPC 9, no 2003 temp. (Volusian); E. Babelon, Les Perses..., nos 2304, 2314; BMC Phoenicia, Tyre, p. 289, no 467 (Valerian); E. BABelon, Les Perses..., no 2346 (Gallienus).
} 
and especially those of Argos in Argolis, where the Palladium was supposedly kept ${ }^{81}$. Here the Palladium appears in three variants as an isolated statue ${ }^{82}$, a small Palladium in a temple ${ }^{83}$, and as one held by Diomedes ${ }^{84}$.

However, the Palladium was introduced rather late into monuments of Roman art. The Palladium held by Anchises, on an intaglio dating from the $1^{\text {st }}$ century $\mathrm{BC}$, should be considered an iconographic peculiarity ${ }^{85}$. Yet, in monetary iconography it was very rarely placed in Aeneas' hands. This idea was present in the coinage of the declining Republic and under Augustus. On the other hand, the denarii struck in the years 27-21 BC in Segesta ${ }^{86}$, feature Aeneas striding, holding the Palladium in his right hand and carrying Anchises, with an eagle behind them while on the earlier denarii struck in $47-46 \mathrm{BC}$ in Africa and associated with C. Julius Caesarr ${ }^{87}$, the figures of Aeneas and Anchises were combined with the symbolic imagery of the Palladium and the sacra. Here the Trojan hero strides, raising the Palladium in his right hand while his father is holding the sacra on his knees (fig. 4).

It remains unknown when the Romans started claiming possession of the Palladium. Records of its presence in Rome are late and there is no evidence of it, and other sacra, being carried over from Lavinium to Rome ${ }^{88}$. Nonetheless, within the period in which the said coins, representing Aeneas with the Palladium, were issued, there was a well-established tradition about the Palladium being pignus imperii, which Cicero expressed in 54 BC: Palladium illud quod quasi pignus nostrae salutis atque imperii custodiis Vestae continetur ${ }^{89}$. So in monetary iconography,

${ }^{81}$ Pausanias, II, 23, 5, [in:] Pausanias, Graeciae Descriptio, ed. M.H. Rocha-Pereira, Leipzig 1973.

${ }^{82}$ Bab. Traité 2/3, Paris 1914, nos 628-629; BMC Peloponnesus, Argos, p. 140, no 48 ( $4^{\text {th }} \mathrm{c} . \mathrm{BC}$ ); RPC 4, no 9662 temp. (Marcus Aurelius); RPC 4, no 5260 temp. (Lucius Verus).

${ }^{83}$ BMC Peloponnesus, Argos, p. 149, no 157; RPC 4, no 4631 temp. (Antoninus Pius); BMC Peloponnesus, Argos, p. 151, no 165 (Septimius Severus).

${ }^{84}$ Bab. Traité $2 / 3$, nos 625-627; BMC Peloponnesus, Argos, p. 139, nos $44-46$ ( $5^{\text {th }}-4^{\text {th }}$ c. BC); BMC Peloponnesus, Argos, p. 148, no 150 (Hadrian); RPC 4, no 3514 temp. (Antoninus Pius).

${ }^{85}$ E.g. intaglio, $1^{\text {st }}$ c. BC, Latakiyah, Paris, Bibl. nat., de Clercq $3131-$ http://medaillesetantiques.bnf. fr/ws/catalogue/app/collection/record/ark:/12148/c33gb1rm1b [17 XII 2015].

${ }^{86}$ BMC Sicily, Segesta, p. 137, nos 65, 66; R. CALCiATI, op. cit., Segesta, p. 305, no 61; RPC 1, no 652; M. Krumme, op. cit., p. 98, Kat. 164/1; cf. S. Mani Hurter, Die Didrachmenprägung von Segesta mit einem Abhang der Hybriden, Teilstücke und Tetradrachmen sowie mit einem Überblick über die Bronzeprägung, Bern 2008, p. 49.

${ }^{87}$ BMCRR East, p. 469, nos 31-35 (48 BC); CRR, no 1013 (48 BC); RRC, no 458/1 (47-46 BC); M. KRumme, op. cit., p. 94, 98-100, Kat. 21/1.

${ }^{88} \mathrm{Cf}$. A. Dubourdieu, Les origines et le développement du culte des Pénates à Rome, Rome 1989, part. p. $460-469$.

${ }^{89}$ Cicero, Scaur. 48, [in:] Cicéron, Discours. Pour M. Aemilius Scaurus, trans. et ed. P. Grimal, Paris 1976. Cf. Serv., Aen. VII, 188: septem fuerunt pignora, quae Imperium Romanum tenent: Faius matris Deum, quadriga fictilis Veientanorum, cineres Orestis, sceptrum Priami, uelum Ilionae, Palladium, ancilia. 
the symbolic scene of saving the father Anchises, the Palladium and the Penates by the Trojan hero generates associations with the idea of persistence and eternity of Imperium Romanum as well as the prosperity of Rome itself: aetheriam servate deam, servabitis urbem: imperium secum transferet illa loci $i^{90}$. Moreover, saved by Aeneas and then kept and carefully guarded in the temple of Vesta ${ }^{91}$, the Palladium could be, as Jane DeRose Evans claims, an allusion to the role of Caesar as pontifex maximus ${ }^{92}$. Such an approach would be both rare and novel. Yet, it is worth following this trace and viewing in a similar, individual context the presence of the Palladium in Aeneas' hand on the coins of Segesta, with the portrait of Augustus on their obverse, and also linking the Palladium itself more clearly with the idea of ruling and authority. These portraits of Aeneas, therefore, may be viewed as a paraphrase of the roles of Caesar and Augustus as in relation to Rome, in the years of the civil wars and afterwards, they fulfill a mission similar to that of Aeneas, who having escaped from the maelstrom of war, reached Latium, founded a city there and governed it. The imagery of Caesar's denarii was especially permeated with such associations, swathing Aeneas in an aura radiating from the Palladium itself but also from the symbolic figure of the father Anchises with a cista containing the sacra.

This last monetary type, used in the times of the Republic and associated with Caesar, was repeated in nummi restituti series issued under Trajan (ca 112/113) ${ }^{93}$. Alexandra Dardaney claims that this republican type found its place in the series due to the image of the Palladium in Aeneas' hand. It was namely the symbol of the power and legitimacy of Trajan's position ${ }^{94}$. Though it is difficult to agree with this opinion - it could be verified only by finding out the inspiration for all the prototypes of restitution coins - the thought of linking the Palladium with the idea of imperial power seems reasonable. It is evident not so much during the reign of the Julio-Claudians, but rather in the later period. When the Julio-Claudian dynasty came to an end in AD 68, the symbol of the Palladium was invoked by the subsequent pretenders to the imperial purple ${ }^{95}$. Likewise, in the following years

\footnotetext{
${ }^{90}$ Ov., Fast. VI, 427-428.

${ }^{91}$ Cf. (e.g.) D.H., II, 66, 3; Cic., Scaur. 48; Cic., Phil. XI, 10, 24, [in:] CicÉron, Discours, Philippiques, trans. et ed. P. Wuilleumier, Paris 1973; Ov., Fast. VI, 445-450; Liv. XXIV, 27, 4; V, 53, 7; Plut., Cam. 20, 5; Serv., Aen. I, 378; II, 166.

${ }_{92}$ J.D. Evans, op. cit., p. 41.

${ }^{93} \mathrm{H}$. Komnick, Die Restitutionsmünzen der frühen Kaiserzeit. Aspekte der Kaiserlegitimation, BerlinNew York 2001, no 38.0; B. Wоутек, Die Reichsprägung des Kaisers Traianus (98-117), Wien 2010, no 836. Cf. M. Krumme, op. cit., p. 104-105, Kat. 48/8.

${ }^{94}$ A. Dardenay, Les mythes..., p. 117.

${ }^{95}$ E.g. RIC $1^{2}$, Galba, no 469. Cf. RIC 1, p. 198: [...] illustration of Galba's rise of power; J.M.C. ToynBEE, The Hadrianic School. A Chapter in the History of Greek Art, Roma 1967, p. 102: symbol of Imperial sovereignty. Palladium appears to have been important in Roman coins iconography, as an attribute of Nobilitas, Roma, Vesta, Victory or emperor. Cf. C. Gatti, Il Palladio sulle monete di Galba, ACRDAC 11, 1980-1981, p. 109-116; R. PERA, L'imperatore ed il divino: il simbolismo del Palladio,
} 
the emperors exploited this motif on their coins yet they did so without referring directly to the figure of Aeneas.

The portraits of Aeneas were enhanced on bronze medallions under the Adoptive and Antonine Emperors: their reverses refer to adventure episodes of the Trojan hero other than the ones described so far, and those that were already known, are pictured in a new way. More intelligible is also the foundational aspect of Aeneas' activity depicted on the medallions.

The first reverse of these medallions was conceived in the following way: in its upper part there is Aeneas carrying Anchises, next to him there is a temple and an altar on one side and a puteal with a tree growing out of it on the other. Below, there is a sow with her piglets, and the bottom part depicts city walls with a gate and towers. Such an image was embossed on the reverse side of Hadrianic medallion dating from the years $\mathrm{AD} 134-138$ (fig. 5) ${ }^{96}$ and repeated later, on undated medallions under Antoninus Pius (fig. 6) ${ }^{97}$.

The occasional character of these medallions and their original reverses confirm that in this case, the picture was designed exclusively for Hadrian's medallion; this reverse iconography was faithfully repeated on Antoninus Pius medallions. In the attempt to find out the sources of this conception, attention was turned towards the above-mentioned sculptures. The characteristic figure of Aeneas with Anchises can be a modified representation of the famous statue from Rome, just like the huge sow. After all, Varro mentions a bronze statue of the sow and her litter in Lavinium ${ }^{98}$. The episodes of Aeneas' life were researched in ancient literature as a possible source of inspiration for this reverse imagery. The Aeneid, with its description of Aeneas' flight from Troy ${ }^{99}$, his encounter with the sow with piglets $^{100}$, and raising the walls around Lavinium ${ }^{101}$ provides a natural nourishment for such associations. An alternative for this is a fragment of the work Alexan-

[in:] La tradizione iconica come fonte storica: il ruolo della numismatica negli studi di iconografia, ed. M. Caccamo Caltabiano, D. Castrizio, M. Puglisi, Reggio Calabria 2004, p. 75-91; P. AssenMaker, Pignus salutis atque imperii. L'enjeu du Palladium dans les luttes politiques de la fin de la République, EC 75, 2007, p. 381-412.

${ }_{96}$ Monnaies Romaines Antiques (collection H.C. Levis), Genève 1925, no 526; M. Krumme, op. cit., p. 104, Kat. 56/1; Abb. 122; P.F. Mittag, Römische Medaillons. Caesar bis Hadrian, Stuttgart 2010, p. 85, Kat. Hadr 98 (132?-138). Cf. J.M.C. ToynbeE, Roman Medallions..., p. 143; G. Giongi, La leggenda delle origini di Roma in un raro medaglione di Adriano, RINSA 3, 1955, p. 85-87; M.S. PoND Rothman, Posthumous Hadrianic Medaillons, ANSMN 23, 1978, p. 111-113; F. Barenghi, Scene leggendarie della storia di Roma su alcuni medaglioni. A proposito del medaglione di Enea e Anchise, RINSA 94, 1992, p. 115-120.

${ }^{97}$ F. Gnecchi, I medaglioni... 2, Ant.P., no 115; M. Krumme, op. cit., p. 104-105, Kat. 57/1 (139 AD). Cf. M.S. Pond Rothman, op. cit., p. 111-113; G.G. Belloni, Celebrazioni epiche in medaglioni di Antonino Pio. Una pagina di cultura erudita, [in:] Serta historica antiqua 2, 1989, p. 198-200.

${ }^{98}$ VARron, RR II, 4, 18, [in:] VARron, Économie rurale, trans. et ed. Ch. Guiraud, Paris 1985.

${ }^{99}$ Verg., Aen. II, 713-716.

${ }^{100}$ Ibidem III, 389-393.

${ }^{101}$ Ibidem VII, 157-159. 
dra by Lycophron of Chalcis. In her prophecy, Cassandra foretold that in the city [Lavinium] Aeneas would raise a statue of a sow (a black one) and her piglets and erect a temple to the goddess Myndia Pallenis [Athena], where he would deposit the statuettes of the household gods [Penates] that he would venerate together with his aged father ${ }^{102}$.

On the medallions of Hadrian and Antoninus Pius one representation accumulates the elements whose meanings merge, mix and symbolically refer to the past, the present and the future of Aeneas ${ }^{103}$. The hero with his father in his arms (though actually he died in Sicily ${ }^{104}$ ) is an allusion to the flight from Troy. It is the past. Then, the present, symbolized by a great sow, is an allusion to the destination he found on Italian land. The future, in turn, might be hidden beneath the image of the city walls, denoting the foundation of a city, Lavinium or Alba Longa ${ }^{105}$. On the other hand, the Penates, to which attention is drawn via the image of a temple and an altar, meld into one concept: the past (saving them from Troy), the present (making an offering), and the future associated with a guarantee of the continuance of the state that possesses them. It is difficult to distinguish one central motif, even though in terms of size, it is the image of the sow which dominates here. The associations evoked are of general kind and refer to the established and canonical deeds of Aeneas and his services to the Romans. On the one side, particular elements of this representation recall the episodes connected with Aeneas' wanderings but on the other side, they relate to his settlement in Latium and point to the foundational aspect in his life story. This chain of associations leads eventually to Rome, although it has not been explicitly recalled by any element of the reverse representation.

Another interesting reverse comes from the medallion of Antoninus Pius dating from the years $\mathrm{AD} 140-143$. The whole scene is oriented towards the left which allows "reading" and combining its individual elements in this order. Aeneas and Ascanius are coming out of a boat onto the shore; their companions are still in the boat. Stretching forth his hand Aeneas points to a cave under a tree and a sow with piglets, while in the background, there are elements of architecture, a round temple, an altar and a puteal (fig. 7) ${ }^{106}$.

\footnotetext{
${ }^{102}$ LyC., Alex. 1259-1265. Cf. Lycophron, Alexandra, p. 449.

${ }^{103}$ Cf. N. Hannestad, Roman Art and Imperial Policy, Aarhus 1986, p. 212-213; M.R. Jenkins, The „Aeneid" Medallion - a Narrative Interpretation, NC 148, 1988, p. 148-152; IDEM, Mythological narrative art..., p. 58-66, 150-152; A. DARDENAY, Les mythes..., p. 120-122; EADEM, Images..., p. 57-62. ${ }^{104}$ See Verg., Aen. III, 707-710. Cf. the suggestion by D.H., I, 64, 5: Anchises died in Latium.

${ }^{105}$ Cf. BMCRE 4, p. xciv: the great Sow standing before the new Troy in Italy, while, in the background, Aeneas carries Anchises between a temple and an altar.

${ }^{106}$ F. GNeCCHI, I medaglioni..., 2, Ant.P., no 99; M. Krumme, op. cit., p. 106, Kat. 67/1. Cf. J.M.C. ToynBeE, Roman Medallions, p. 221-222; G.G. BeLloni, op. cit., p. 201; M.R. Jenkins, Mythological narrative art..., p. 114-121; A. DARDENAY, Les mythes..., p. 123-125; EADEM, Les héros fondateurs de Rome, entre texte et image à l'époque romaine, Pall 93, 2013: Texte et image dans l'Antiquité, ed. J.-M. LuCE, p. 175-176.
} 
Compared with the reverse discussed earlier, this medallion of Antoninus Pius exhibits a significant structural change which consists of replacing Anchises with Ascanius and introducing an image of a boat reaching the shore. The most significant compositional change, however, is moving the elements of architecture into the background and placing the newcomers from Troy and the sow found on the river shore on the same plane, as Helenus foretold in his prophecy:

cum tibi sollicito secreti ad fluminis undam
litoreis ingens inuenta sub ilicibus sus
triginta capitum fetus enixa iacebit,
alba solo recubans, albi circum ubera nati,
is locus urbis erit, requies ea certa laborum ${ }^{107}$.

The motif of the sow and her piglets was more frequently present in Roman coinage. The story of Aeneas' arrival in Italy, after his long journey, and finding a white sow with thirty piglets in a secluded place under an oak tree, which according to the prophecy, designated the end of his wanderings, found expression in the coinage minted under Vespasian, Hadrian and - especially - Antoninus Pius ${ }^{108}$. The image of a sow with her piglets sufficed, their number changing, sometimes the motif of a tree was introduced. On the medallion of Antoninus Pius just described - via the figures of Aeneas and his son Ascanius and through the elements of a temple architecture of Lavinium or rather Alba Longa - the motif of the sow was combined with the essence of the story about the Trojan hero as the progenitor of the Romans. From this image, as Amedeo Giampaglia notes, the associations quite easily drift towards the twins fed by the she-wolf under ficus ruminalis ${ }^{109}$.

In iconographic and semantic terms the image of Aeneas from the medallion of Antoninus Pius was integrated into "future" events only. The abandonment of the Trojan past is rendered by another iconographic detail: Aeneas and Ascanius are getting out of the boat. At this point the provincial emissions of Antandrus struck in the times of the Severan dynasty form an intriguing opposition to this medallion of Antoninus Pius. They depict a scene of leaving Troas in which Aeneas, carrying his father in his arms and with his son at his side, is heading towards a boat ${ }^{110}$. A certain iconographic parallel with this solution is solely the scene of the

\footnotetext{
${ }^{107}$ Verg., Aen. III, 389-393. Cf. too ibidem VIII, 81-83.

${ }^{108}$ Vespasian - RIC 2/1, Vesp. nos 982-983; RIC 2/1, Tit., under Vesp., no 986; Hadrian - F. GNECCHI, I medaglioni..., 3, Adr., nos 155, 156; P.F. MittaG, op. cit., Kat. Hadr 21; Antoninus Pius - F. GneCCHI, I medaglioni..., 3, Ant.P., no 144; RIC 3, Ant.P., nos 629, 722, 733, 768. Cf. A. Alföldi, Early Rome and the Latins, Ann Arbor 1965, p. 271-273.

${ }^{109}$ A. Giampaglia, op. cit., p. 154.

${ }^{110}$ C. Fontana, op. cit., p. 54, no 18 (Caracalla); A. Giampaglia, op. cit., p. 160; https://www. cngcoins.com/Coin.aspx?CoinID=114901 [13 IV 2016] (Severus Alexander).
} 
flight from Troy on the Tabula Iliaca Capitolina, in which Ascanius, Aeneas and Anchises with the sacra are setting out for Hesperia ${ }^{111}$.

Another interesting reverse representation referring to Aeneas is on a medallion with the portrait of caesar Marcus Aurelius on its obverse (ca 145-146). It features a sacrificial offering of pig meat, a sacrificer capite velato, a young man in a Phrygian cap but also victimarii and in the background - a temple (fig. 8) ${ }^{112}$. The main protagonists of this scene are said to be Aeneas and Ascanius. Besides this, in terms of composition, this representation bears a likeness to the panel of Ara Pacis. Yet, a number of doubts arise in connection with Paul Rehak's hypothesis that on the Ara Pacis it is not Aeneas but Numa Pompilius making an offering to the Penates ${ }^{113}$. Still, it is certain that the image on the medallion conveys both symbolic and conventional meaning.

It cannot be excluded that another episode associated with Aeneas' presence on Italian land was recalled on other medallions from the times of Antoninus Pius: two foot warriors are fighting each other; one of them has already brought the other down to his knees ${ }^{114}$. Here Jocelyn M.C. Toynbee allows for a possibility that it is a duel between Aeneas and Turnus ${ }^{115}$.

Even more precisely, but also more metaphorically, the interrelation between Aeneas and the history of the Romans is reflected on still other medallions of Antoninus Pius (AD 158). In their reverse iconography, Roma, sitting on a rock or on a shield under a tree, is holding out her hand to a man in armour and paludamentum who is standing opposite her, while another woman with a bundle on her head and a child in a Phrygian cap and with pedum are standing behind the man (fig. 9) ${ }^{116}$. According to Robert Turcan, it is Aeneas who is holding Roma's hand and the persons standing behind him are Launa or Lavinia and Ascanius ${ }^{117}$. Here, the exile from Troy has been juxtaposed with the figure Roma, which conveys various meanings. Dea Roma was a personification of the Roman people, the city and the whole

\footnotetext{
${ }^{111}$ Cf. A. SAdurska, Les Tables Iliaques, Warszawa 1964, p. 29, no 1A.

${ }^{112}$ F. GnecChi, I medaglioni..., 2, M.Aur., no 84; H. Dressel, op. cit., p. 65-69, no 33; M. Krumme, op. cit., p. 107-110, Kat. 85/1. Cf. J.M.C. ToynbeE, Roman Medallions..., p. 218-219; A. DARdenAY, Images..., p. 63-65.

${ }^{113}$ P. RehaK, Aeneas or Numa? Rethinking the Meaning of the Ara Pacis Augustae, ArtB 83.2, 2001, p. 190-208.

${ }^{114}$ F. GNecchi, I medaglioni..., 2, Ant.P., no 119.

115 J.M.C. Toynbee, Roman Medallions..., p. 146, n. 197. Cf. M.R. Jenkins, Mythological narrative art..., p. 159-161; F. Marcattili, Et ipsa suis deplangitur Ardea pennis. Enea, Turno et le ceneri di Ardea in un medaglione di Antonino Pio, RINSA 117, 2016, p. 117-128. See Verg., Aen. XII, 896-907, cf. ibidem XII, 926-927 and 950-952.

${ }^{116}$ F. GNECCHI, I medaglioni... 2, Ant.P., no 57.

${ }_{117}$ R. Turcan, Numismatique romaine du culte métroaque, Leiden 1983, p. 32-34. Cf. W. FroenNER, Les médaillons de l'Empire romain depuis le règne d'Auguste jusqu'à Priscus Attale, Paris 1878, p. 64-65: Aeneas, Iulus, Italia and Vesta; F. GNecchI, I medaglioni..., 2, Ant.P., p. 15, no 57: Antoninus Pius, Atys, Rome and Cybele.
} 
imperium populi Romani; she was also associated with the person of the emperor and, as Roma aeterna, became a symbol of eternity and the continuance of Rome ${ }^{118}$.

Two types of provincial coins of Ilium build a framework for such an expression of the relation between Aeneas and Rome, as on the medallions of Antoninus Pius. The first type of coins is bronzes date from the times of Hadrian (AD 117-138). Their reverse representations show the Aeneas group and - in exergue - the she-wolf with the twins (fig. 10) ${ }^{119}$. This fusion of two symbols, of which the first refers to a Trojan myth and the other to a Roman one, is a unique solution in the coinage. Equally interesting, in this perspective of linking the "eastern" Aeneas with the "Italian" context is a bronze coin from the times of Elagabalus (AD 218-222). The reverse inscription I $\Lambda \mathrm{I} \Omega \mathrm{N}$ AINEIAC $\mathrm{P} \Omega \mathrm{MH}$, is illustrated with images of Tyche and Aeneas giving over the Palladium to Roma who is standing opposite him ${ }^{120}$. Here Aeneas is both a Trojan and the one, who as the donor of the Palladium, causes the advent of Rome and its continuance. It may be another metaphor of Aeneas' role as the founder of Rome.

The material presented in this study reveals the diversity of the numismatic representations relating to Aeneas. On the one hand he is perceived as profugus, and on the other, as fundator. However, these two portraits of Aeneas do not stand in opposition to each other; the second is rather the continuation of the first. They also provide a frame for such virtues and features of Aeneas as pius and penatiger connoted through the representations.

Various portraits of Aeneas in Roman coinage are created exclusively via images. Even the name of Aeneas - apart from above-mentioned provincial bronzes of Ilium, issued under Elabagalus - was not introduced into the inscriptions on Roman coins and medallions. Nonetheless he is clearly recognizable as the main protagonist of the Aeneas group that was so popular in the coinage. In the majority of other iconographic solutions, discussed in the present study, the references to Aeneas do not raise doubt. On the other hand, as to the remaining imagery, there are presumptions based on the 'canonical' ways of presenting the figure of the Trojan hero but also on some of his attributes and on the possibility of integrating the reverse scene into certain themes of a more widespread tradition, in order to enrich the group of coins and medallions with the Aeneas motif in Roman coinage by assuming that it is Aeneas who is represented on them. In further research it would be worth paying closer attention to the political context of the coins and medallions reviewed in the present study.

The coins of the Republican epoch and the first years of the Empire, exhibit the potential attractiveness of the figure of Aeneas for the issuers of coins. However, the Aeneas motif was rarely exploited on the coins and few iconographic solutions

${ }^{118}$ Cf. R. Mellor, The Goddess Roma, [in:] ANRW II, vol. XVII.2, ed. W. HaAse, Berlin-New York 1981, p. 950-1030.

${ }^{119}$ vF Ilion, no 55; SNG vA, no 1533; A.R. Bellinger, op. cit., no T 134; RPC 3, no 1570.

${ }^{120}$ https://www.pecunem.com/auction-24/lot-296 [17 XII 2015). 
were introduced. Here the fundamental difference between the emissions of the Roman Republic and those from the times of the Empire consists in the fact that at the beginning, the figures of Aeneas and Anchises sufficed while the figure of Ascanius was introduced quite late. It was a reminiscence of the statuary type of the Aeneas Group.

In the times of the Empire all types of coins repeated the same schematic image of the Aeneas group. In this context the reverses of the medallions dating from the times of the Adoptive and Antonine Emperors, which combined various scenes and details to render symbolically different episodes from Aeneas' life, look interesting. On the other hand, compared with these solutions, the models occasionally used, in which the power of associations resides in the personification of Roma and the She-wolf and the twins, look original. The coherence between the figure of Aeneas and Roman history was accentuated in this way.

\section{Bibliography}

\section{Secondary literature}

AichHolzer P., Darstellungen römischer Sagen, Wien 1983.

Alföldi A., Alföldi E., Clay C.L., Die Kontorniat-Medaillons, Berlin 1976.

Alföldi A., Die trojanischen Urahnen der Römer, Basel 1957.

Alföldi A., Early Rome and the Latins, Ann Arbor 1965.

Assenmaker P., Pignus salutis atque imperii. L'enjeu du Palladium dans les luttes politiques de la fin de la République, EC 75, 2007, p. 381-412.

Bab. Traité = BABelon E., Traité des monnaies grecques et romaines, Paris 1907, 1910, 1914, 1926.

Bab. Wadd. = Inventaire sommaire de la Collection Waddington [...], ed. E. BABELON, Paris 1898.

Babelon E., Les Perses Achémenides, les satrapes et les dynasties tributaires de leur empire, Cypre \& Phénicie, Paris 1893.

BARENGHI F., Scene leggendarie della storia di Roma su alcuni medaglioni. A proposito del medaglione di Enea e Anchise, RINSA 94, 1992, p. 113-120.

Bellinger A.R., Troy. The Coins, Princeton 1961.

Belloni G.G., Celebrazioni epiche in medaglioni di Antonino Pio. Una pagina di cultura erudita, [in:] Serta historica antiqua 2, 1989, p. 191-205.

Bettini M., Lentano M., Il mito di Enea. Immagini e racconti dalla Grecia a oggi, Torino 2013.

Bitto I., M. Herennio, il mito eneico, la dea Herentas, [in:] La tradizione iconica come fonte storica: il ruolo della numismatica negli studi di iconografia, ed. M. Caccamo Caltabiano, D. Castrizio, M. Puglisi, Reggio Calabria 2004, p. 385-398.

Biтto I., Per una proposta di interpretazione del denarius del monetiere M. Herennius con leggenda PIETAS, Messana 3, 1990, p. 147-168.

$B M C=A$ Catalogue of the Greek Coins in the British Museum, ed. R.S. Poole, London 1873-1927. 
BMCRE $=$ A Catalogue of the Roman Coins in the British Museum. Coins of the Roman Empire in the British Museum, ed. H. Mattingly, London 1965-1976 (reed.).

BMCRR - Grueber H.A., Coins of the Roman Republic in the British Museum, London 1910.

Calciati R., Corpus nummorum siculorum: la monetazione di bronzo, Milano 1983-1987.

Caltabiano M.C., Gli eroi omerici nella tipologia monetale antica, RINSA 90, 1988, p. 27-44.

CAnciani F., Aineias, [in:] Lexicon iconographicum mythologiae classicae, ed. L. KAHIL, vol. I.1, Zürich-München 1981, p. 381-396.

CAPPelli R., Questioni di iconografia, [in:] Roma, Romolo, Remo e la fondazione della città. Roma, ed. A. Carandini, R. Cappelli, Milano 2000, p. 151-183.

CRR = Sydenham E.A., The Coinage of the Roman Republic, London 1952.

DARDENAY A., Le rôle des ateliers de lampes dans la diffusion iconographique de la fuite d'Énée, MCV 35.2, 2005, p. 161-189.

Dardenay A., Images des Fondateurs. D'Enée à Romulus, Bordeaux 2012.

Dardenay A., Les héros fondateurs de Rome, entre texte et image à l'époque romaine, Pall 93, 2013: Texte et image dans l'Antiquité, ed. J.-M. LuCE, p. 165-184.

DARDENAY A., Les mythes fondateurs de Rome. Images et politique dans l'Occident romain, Paris 2010.

Dressel H., Die römischen Medaillone des Münzkabinetts der Staatlichen Museen zu Berlin, rev. K. RegLing, Dublin-Zürich 1973.

Dubourdieu A., Les origines et le développement du culte des Pénates à Rome, Rome 1989.

Duncan T., The Aeneas Legend on Coins, CJ 44, 1948/1949, p. 15-29.

ERskine A., Troy between Greece and Rome. Local tradition and imperial power, Oxford 2001.

Evans J.D., The Art of Persuasion, Political Propaganda from Aeneas to Brutus, Ann Arbor 1992.

Fontana C., Note su alcune monete inedite o poco conosciute della serie urbica greca coniate durante l'Impero Romano, RINSA 18, 1967, p. 39-62.

Froenner W., Les médaillons de l'Empire romain depuis le règne d'Auguste jusqu'à Priscus Attale, Paris 1878.

Fuchs G., Architekturdarstellungen auf römischen Münzen der Republik und der frühen Kaiserzeit, Berlin 1969.

Fuchs W., Die Bildgeschichte des Flucht des Aeneas, [in:] ANRW, vol. I.4, ed. H. Temporini, BerlinNew York 1973, p. 615-632.

Gaebler H., Die antiken Münzen Nord-Griechenlands, Bd. 3, Makedonia und Paionia, Berlin 1935.

Galinsky G.K., Aeneas, Sicily, and Rome, Princeton 1969.

Gatti C., Il Palladio sulle monete di Galba, ACRDAC 11, 1980-1981, p.109-116.

Giampaglia A., Enea, il fondatore: Roma e la Troade a confronto, [in:] Polis, urbs, civitas, moneta e identità, ed. L. Travaini, G. Arrigoni, Roma 2013, p. 151-163.

Giongi G., La leggenda delle origini di Roma in un raro medaglione di Adriano, RINSA 3, 1955, p. 84-87.

GNeCCHI F., I medaglioni romani, descritti ed illustrati, Milano 1912.

Hannestad N., Roman Art and Imperial Policy, Aarhus 1986.

Harl K.W., Civic Coins and Civic Politics in the Roman East A.D.180-235, Berkeley-Los AngelesLondon 1987.

Hexster O., Emperors and Ancestors: Roman Rulers and the Constraints of Tradition, Oxford 2015. 
Horsfall N., The Iconography of Aeneas' Flight: a Pratical Detail, AK 22.2, 1979, p. 104-105.

Horsfall N.M., Aeneas the colonist, Verg 35, 1989, p. 8-27.

Horsfall N.M., The Aeneas-Legend from Homer to Virgil, BICS 34, 1987, Suppl. Nr 52: Roman Myth and Mythography, p. 12-24.

Howgego Ch., Coinage and Identity in the Roman Provinces, [in:] Coinage and Identity in the Roman Provinces, ed. Ch. Howgego, V. Heuchert, A. Burnett, Oxford-New York 2005, p. 1-17.

Jenkins M.R., Mythological narrative art in Roman numismatics, Diss. Univ. of Tasmania 1991.

Jenkins M.R., The „Aeneid” Medallion - a Narrative Interpretation, NC 148, 1988, p. 148-152.

Kendall A., The depictions of Aeneas in Roman numismatic and medallic art, The Picus 1996, p. 22-37.

Komnick H., Die Restitutionsmünzen der frühen Kaiserzeit. Aspekte der Kaiserlegitimation, BerlinNew York 2001.

Kraft K., Das System der kaiserzeitlichen Münzprägung in Kleinasien. Materialien und Entwürfe, Berlin 1972.

KRumme M., Römische Sagen der antiken Münzprägung, Marburg 1995.

LACRoIX L., Les reproductions de statues sur les monnaies grecques, Liège 1949.

Lindner R., Mythos und Identität: Studien zur Selbstdarstellung kleinasiatischer Städte, Stuttgart 1994.

Mani Hurter S., Die Didrachmenprägung von Segesta mit einem Abhang der Hybriden, Teilstücke und Tetradrachmen sowie mit einem Überblick über die Bronzeprägung, Bern 2008.

Marcattili F., Et ipsa suis deplangitur Ardea pennis. Enea, Turno et le ceneri di Ardea in un medaglione di Antonino Pio, RINSA 117, 2016, p. 117-128.

MARTIN J.-P., Les thèmes de l'épopée romaine dans la numismatique impériale, [in:] Imago Antiquitatis. Religions et iconographie du monde romain. Mélanges offerts à Robert Turcan, ed. N. BLANC, A. Buisson, Paris 1999, p. 329-340.

Martin P.M., Sur un prodige délivré à Énée (D.H., I, 59, 4-5): essai d’interprétation, REL 64, 1986, p. 38-58.

Mc Innis C., Foundation Iconography on Roman Coins: A Study of the Romulus and Remus and Aeneas Legends, CMNSJ 2.1, 2001, p. 5-22.

Mellor R., The Goddess Roma, [in:] ANRW, II, vol. XVII.2, ed. W. HaAse, Berlin-New York 1981, p. $950-1030$.

Mielczarek M., Mennictwo starożytnej Grecji. Mennictwo okresów archaicznego i klasycznego, vol. I, Warszawa-Kraków 2006.

Mittag P.F., Römische Medaillons. Caesar bis Hadrian, Stuttgart 2010.

Monnaies Romaines Antiques (collection H.C. Levis), Genève 1925.

Pera R., L'imperatore ed il divino: il simbolismo del Palladio, [in:] La tradizione iconica come fonte storica: il ruolo della numismatica negli studi di iconografia, ed. M. CaCcamo Caltabiano, D. Castrizio, M. Puglisi, Reggio Calabria 2004, p. 75-91.

Petrillo Serafin P., La pietas di Enea: due monete a confronto, BA 13, 1982, p. 35-38.

Pond Rothman M.S., Posthumous Hadrianic Medaillons, ANSMN 23, 1978, p. 107-128.

Price M., Waggoner N., Archaic Greek Coinage. The Asyut Hoard, London 1975.

Reнак P., Aeneas or Numa? Rethinking the Meaning of the Ara Pacis Augustae, ArtB 83.2, 2001, p. 190-208. 
RIC $=$ The Roman Imperial Coinage, ed. H. MatTIngly et al., London 1923 sqq.

Rimell V., The Closure of Space in Roman Poetics. Empire's Inward Turn, Cambridge 2015.

$R P C=$ Roman Provincial Coinage Online. http://rpc.ashmus.ox.ac.uk/

$R P C=$ Roman Provincial Coinage, vol. 1, ed. A. Burnett, M. Amandry, P.P. Ripollès, London-Paris 1992.

RRC = CrAWFORD M.H., Roman Republican Coinage, Cambridge 1974.

SAdurska A., Les Tables Iliaques, Warszawa 1964.

Sмith R.R.R., Myth and Allegory in the Sebasteion, [in:] Aphrodisias Papers: Recent work on architecture and sculpture, ed. Ch. Roueché, K.T. ERIM, JRA Suppl. 1, 1990, p. 89-100.

SNG vA = Sylloge Nummorum Graecorum Deutschland: Sammlung von Aulock, rev. G. KLeINER et al., Berlin 1957-1968.

TEXIER R., A propos de deux représentations archaïques de la fuite d'Énée, RA $14,6^{\text {th }}$ s., 1939, p. $12-21$.

ToynbeE J.M.C., Roman Medallions, New York 1986.

Toynbee J.M.C., The Hadrianic School. A Chapter in the History of Greek Art, Roma 1967.

Turcan R., Numismatique romaine du culte métroaque, Leiden 1983.

Vanotti G., L’altro Enea. La testimonianza di Dionigi di Alicarnasso, Roma 1995.

vF Ilion $=$ H. von Fritze, Die Münzen von Ilion, [in:] Troja und Ilion: Ergebnisse der Ausgrabungen in den vorhistorischen und historischen Schichten von Ilion 1870-1894, ed. W. DöRPFELD, 2, Athen 1902, p. 477-534.

vA Phrygiens = H. von Aulock, Münzen und Städte Phrygiens, Tübingen 1980.

Woyteк B., Die Reichsprägung des Kaisers Traianus (98-117), Wien 2010.

Zanker P., August i potęga obrazów, trans. L. Olszewski, Poznań 1999.

Abstract. On the basis of numismatic material I present aspects of the figure of Aeneas as they appear in ancient tradition. I have concentrated on the iconographic details and the arrangement of the reverse scenes which allow one to isolate the elements of Aeneas's portrait in the coinage that are closely associated with his role as the one who, by carrying over the sacra to Italy, made way for the foundation and continuation of Rome.

Keywords: Aeneas, Troy, Rome, Roman coins, Roman medallions, iconography of Roman coin types.

Agata A. Kluczek

Uniwersytet Śląski w Katowicach Wydział Nauk Społecznych Instytut Historii

Zakład Historii Starożytnej ul. Bankowa 11, p. 134

40-007 Katowice, Polska/Poland agata.kluczek@us.edu.pl 


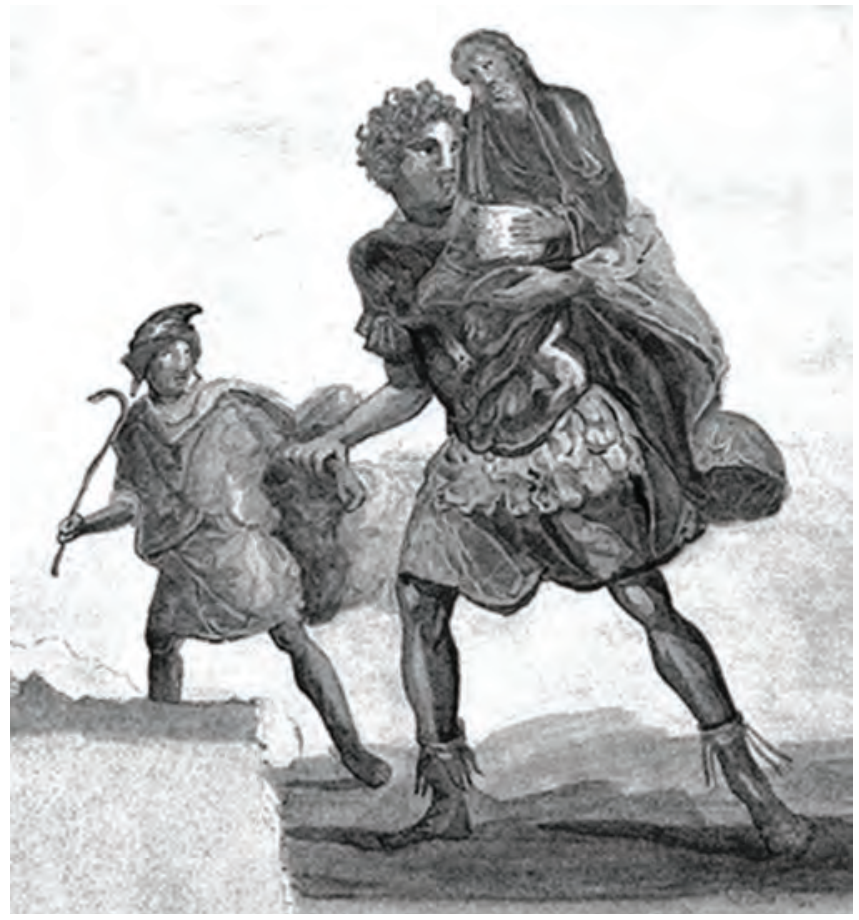

Fig. 1. Wall painting (copy), $1^{\text {st }}$ century AD, Pompeii, Aeneas carrying Anchises and leading Ascanius, Museo della Civiltà Romana.

Fig. 2. Terracotta figurine, $1^{\text {st }}$ century AD, Pompeii, Aeneas carrying Anchises and leading Ascanius, Museo Archeologico Nazionale di Napoli 110338, W.H. Roscher, Ausführliches Lexikon der Griechischer und Römischen Mythologie, 1, Leipzig 1884, col. 163.

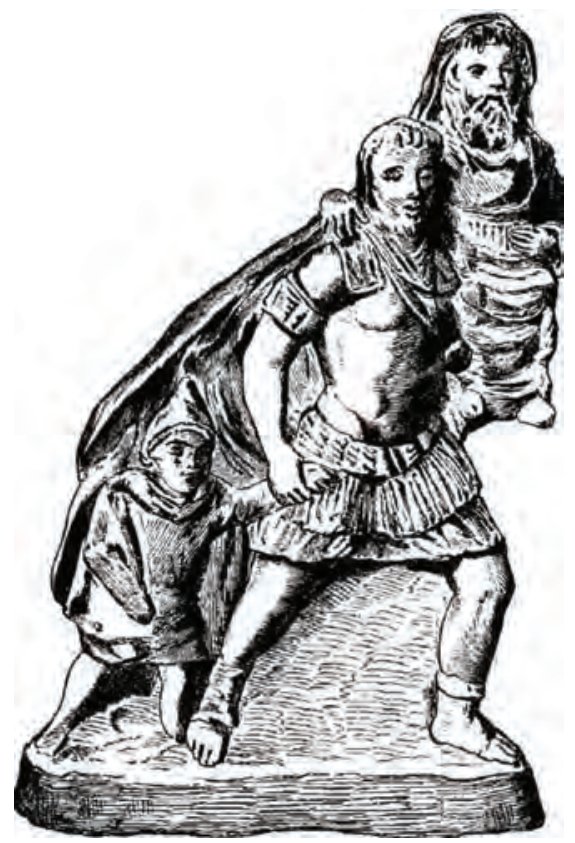



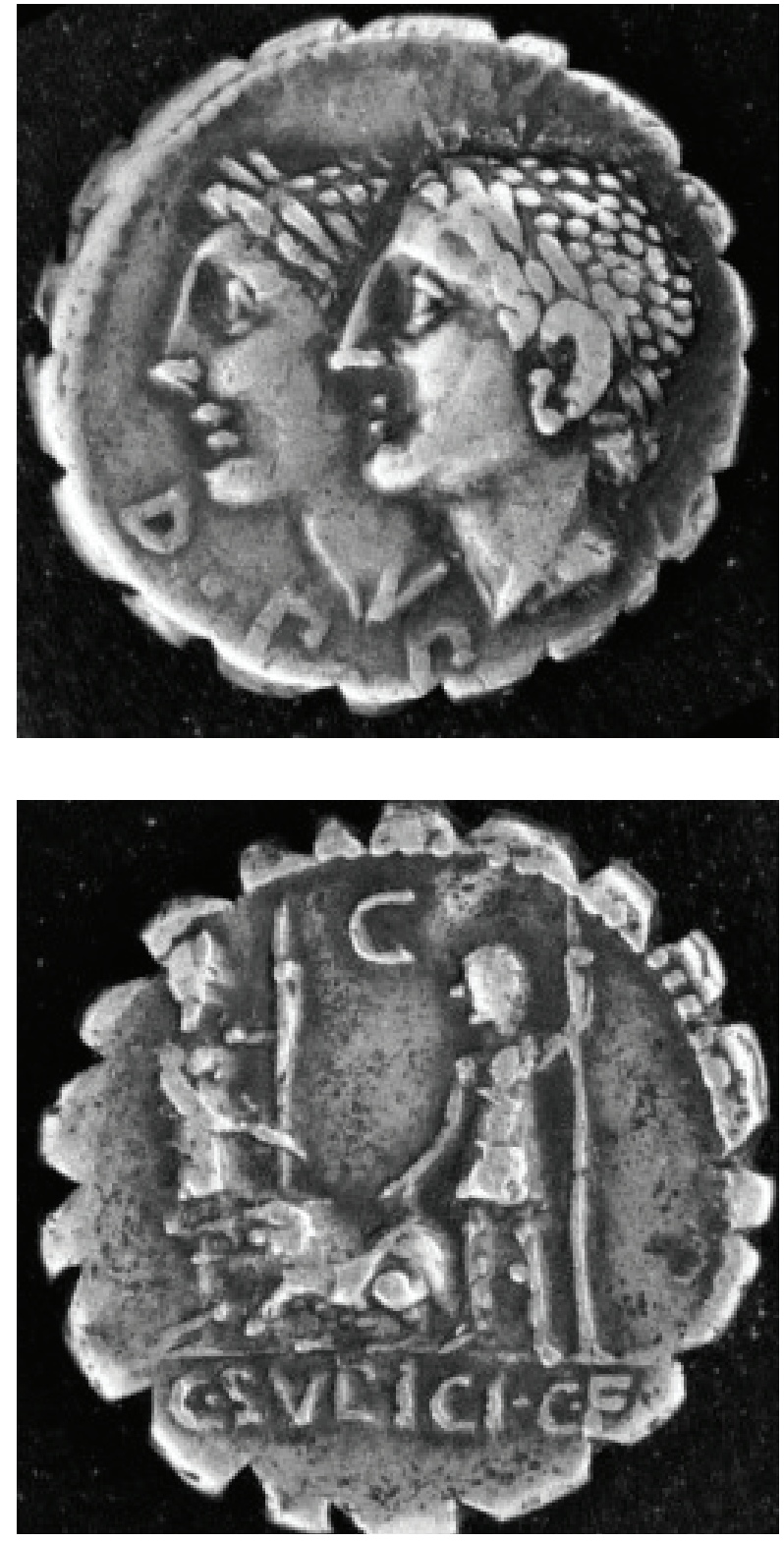

Fig. 3. D, serratus, Rome, 106 BC, Obv. D P P, jugate heads of Dii Penates, Rv. C, two soldiers standing facing each other, holding spears and pointing at a sow which lies between them, in exergue C SVlPICI C F, cf. M.H. Crawford, Roman Republican Coinage, Cambridge 1974, nr 312/1. 


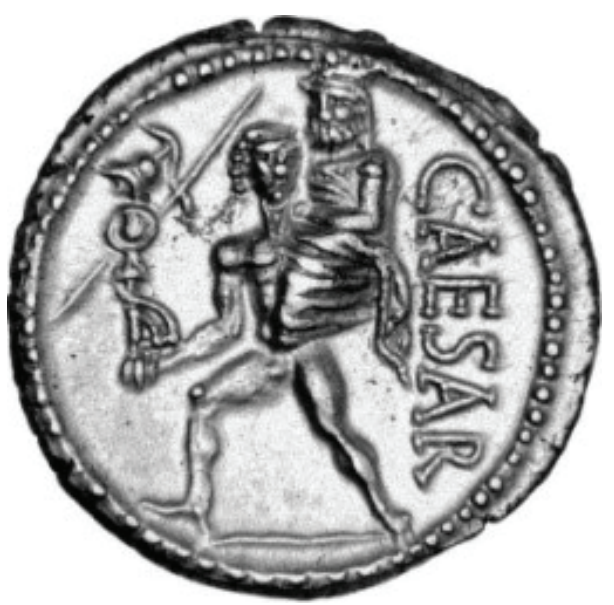

Fig. 4. D, African mint, 47-46 BC, Rv. CAESAR, Aeneas, advancing to the left, holding the palladium in his hand, and Anchises on his shoulder, cf. M.H. Crawford, Roman Republican Coinage, Cambridge 1974, nr 458/1.

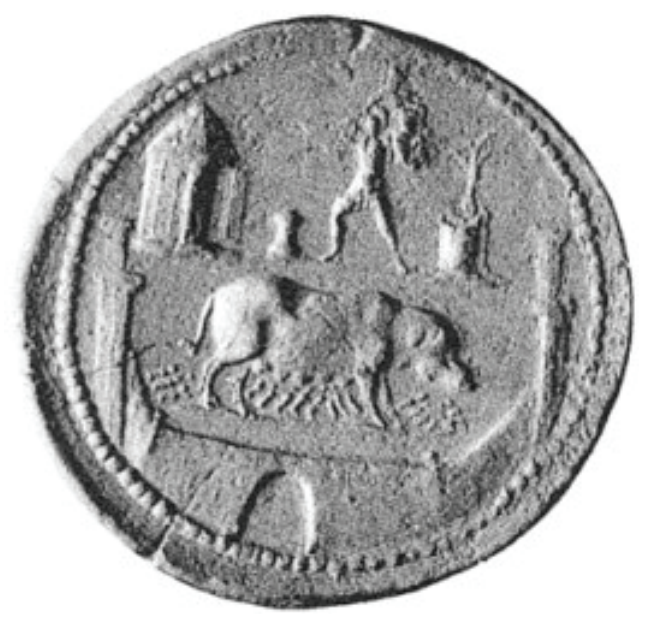

Fig. 6. ÆM, Rome, Antoninus Pius, [AD 138-161], Rv. Aeneas, carrying Anchises, ara, puteal, Great Sow, walls and architectural features, cf. F. GNECCHI, I medaglioni romani, descritti ed illustrati, Milano 1912, 2, tav. 55, 8.

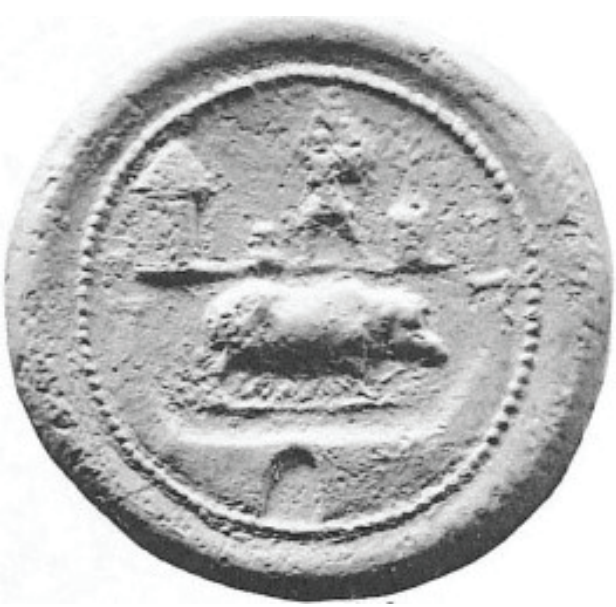

Fig. 5. ÆM, Rome, Hadrian, AD 134-138, Rv. Aeneas, carrying Anchises, ara, puteal, Great Sow, walls and architectural features, cf. Monnaies Romaines Antiques (collection H.C. Levis), Genève 1925, pl. 21, nr 526.

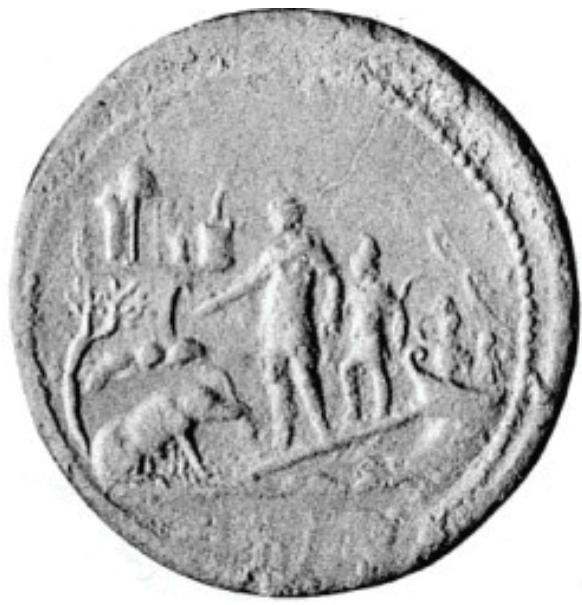

Fig. 7. ÆM, Rome, Antoninus Pius, AD 140-143, Rv. Aeneas, Ascanius, Great Sow, prow of the boat, architectural features, puteal, cf. F. GNeCCHI, I medaglioni romani, descritti ed illustrati, Milano 1912, 2, tav. 54, 9. 

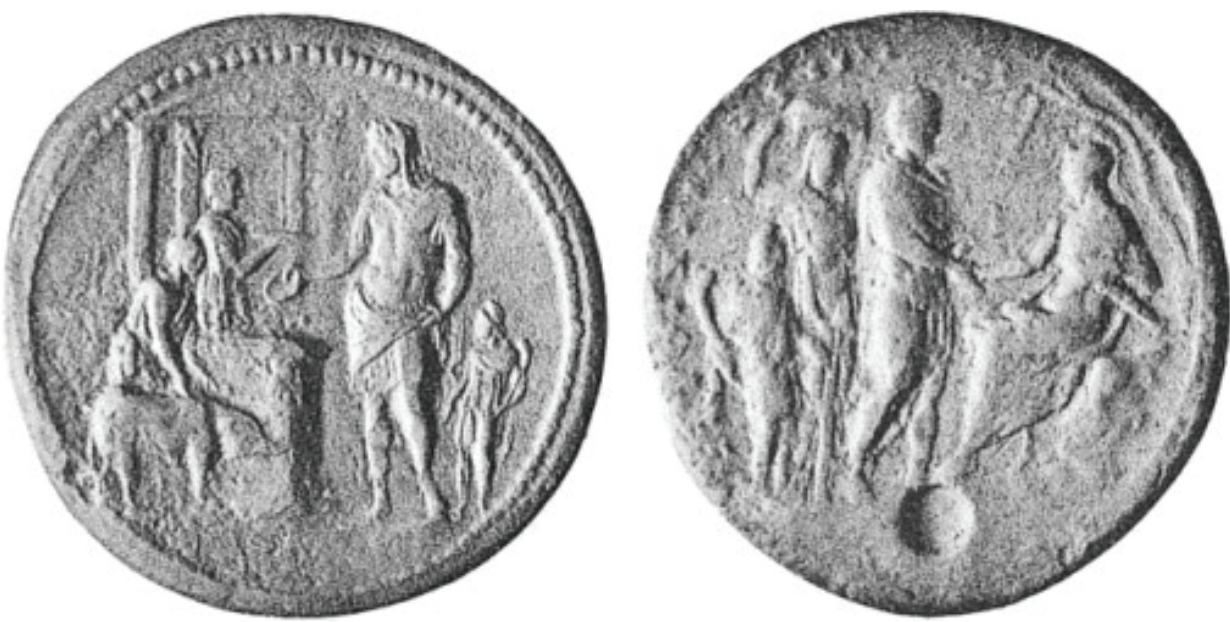

Fig. 8. ÆM, Rome, Antoninus Pius, c. AD 145-146, Fig. 9. ÆM, Rome, Antoninus Pius, AD 158, Rv. Aeneas capite velato, with patera, behind him Rv. TR P XXI COS IIII, Roma seated 1., facing Ascanius, victimarius holds the sow, ara, woman, Aeneas? Behind him the woman and Ascanius? in background temple, cf. F. GNECCHI, I medaglio- cf. F. GNECCHI, I medaglioni romani, descritti ed ni romani, descritti ed illustrati, Milano 1912, 2, illustrati, Milano 1912, 2, tav. 50, 1. tav. 66, 6 .

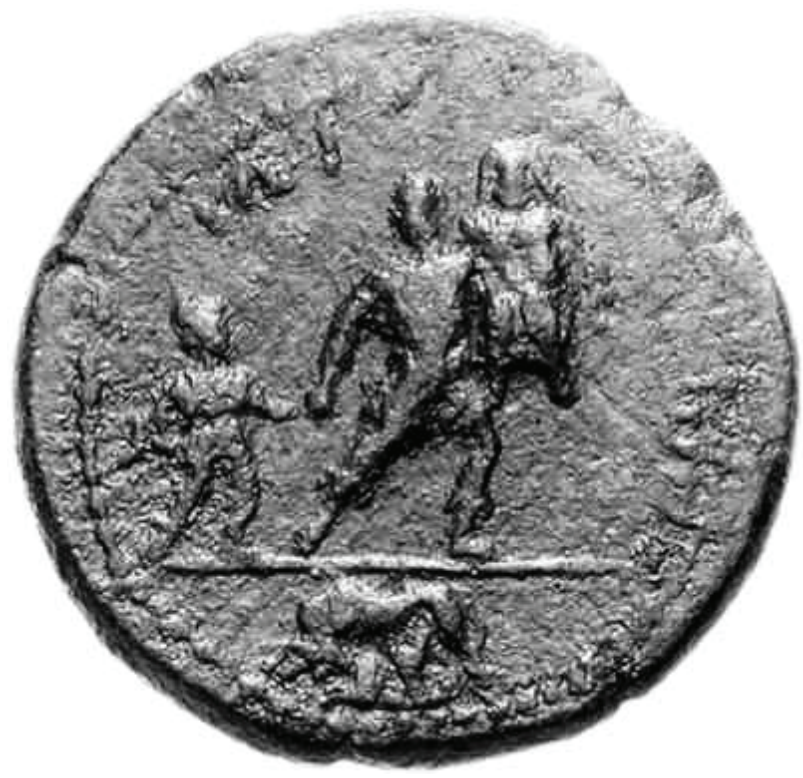

Fig. 10. Æ, Ilium, Hadrian, [AD 117-138], Rv. I II E $\Omega N$, Aeneas carrying Anchises and leading Ascanius, in the exergue, She-wolf and twins, cf. H. von Fritze, Die Münzen von Ilion, [in:] Troja und Ilion: Ergebnisse der Ausgrabungen in den vorhistorischen und historischen Schichten von Ilion 1870-1894, ed. W. Dörpfeld, 2, Athen 1902, Nr 55, Beilage 62 